\title{
What Is the Role of A Student Music Therapist in a Community Music Setting?
}

An exegesis presented in partial fulfilment for the degree of

\author{
Master of Music Therapy
}

New Zealand School of Music

Wellington, New Zealand

Sidharth Pagad

2014 


\section{ABSTRACT}

This qualitative research project set out to explore my role as a student music therapist within a community music setting. I am a student music therapist, working with a community music company involved in a variety of community music groups and projects. I wanted to understand what I might offer the community music company by bringing a community music therapy perspective to the work.

The research involved an exploration into the literature relating to Community Music Therapy as well as Community Music and required me to regularly question the reasoning and philosophy behind Community Music Work. To answer my question I engaged in secondary analysis of data generated during the first 24 weeks at this community music placement. The data included session notes, audio recordings of supervision sessions, and my reflective journal.

The literature includes examples of collaboration between community music therapists and community musicians, and I sought to experience this at my placement. The hoped for collaboration did take place during the period of data collection, enabling detailed reflections of it. This exploration therefore helped me to develop as a community musician and music therapy student.

The practice was broad and involved regular transitions in role, often within the same session. These included participant, accompanist, song-leader, community music therapist, and drum circle facilitator. Findings suggest that Community Music and Community Music Therapy are disciplines with many similarities in appearance and structure, but tend to diverge when looking at goals and overall objectives and foci.

Social equality seems to be commonly shared value between Community Music and Community Music Therapy. The ways in which this value is acted upon is also explored.

Performance and Performativity as aspects of group behaviour was found to be mentioned in the literature, and again this was mentioned in the data collected as part of the researcher's placement. 


\section{TABLE OF CONTENTS}

Abstract...

Table of Contents

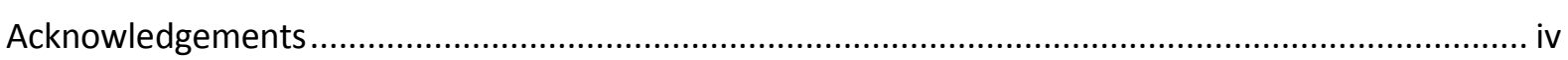

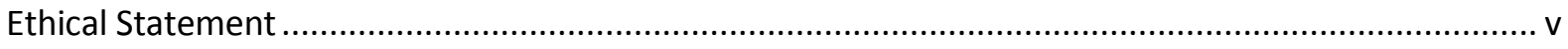

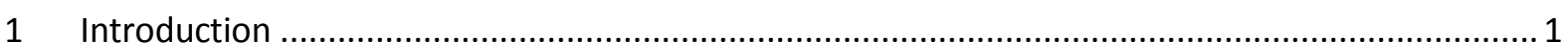

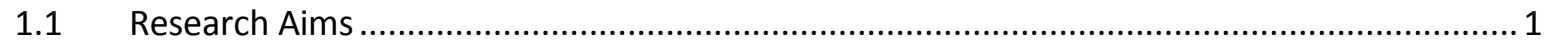

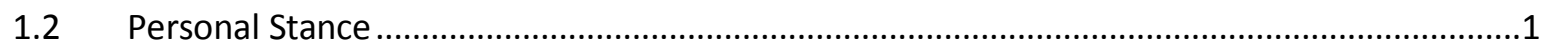

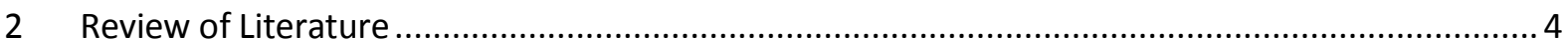

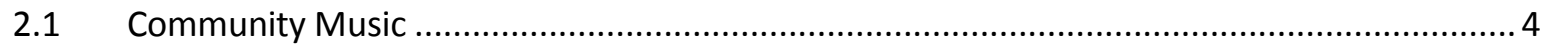

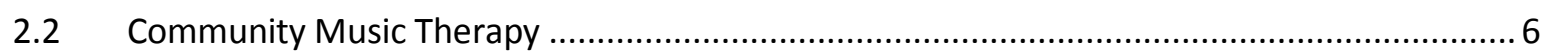

2.3 Commonalities, Distinctions and Opportunities for Collaboration ..................................... 8

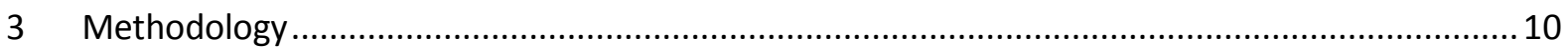

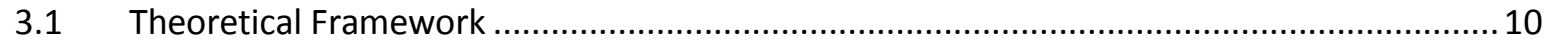

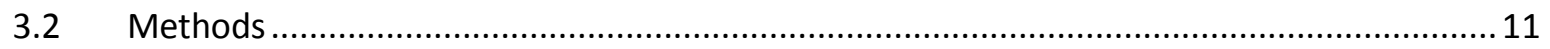

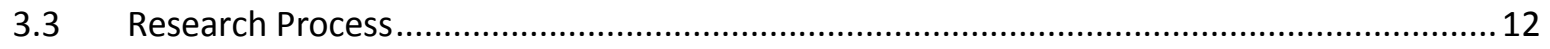

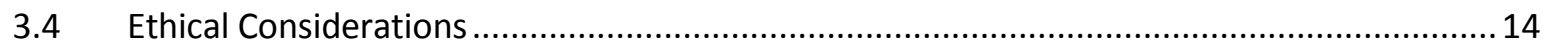

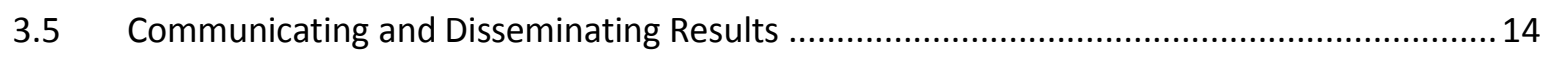

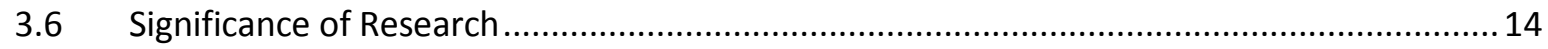

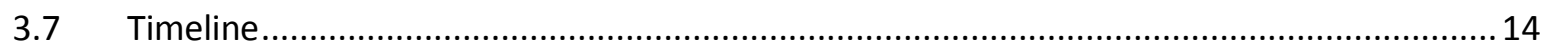

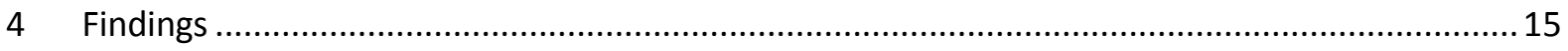

4.1 My personal journey as a student music therapist in my second year placement................ 15

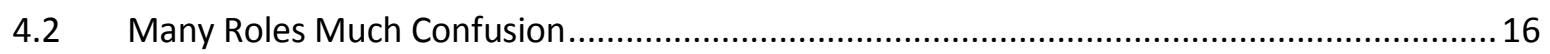

4.3 Feeling Overwhelmed and Building Musical Skills........................................................ 18

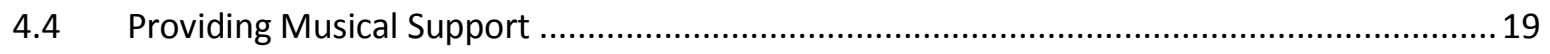

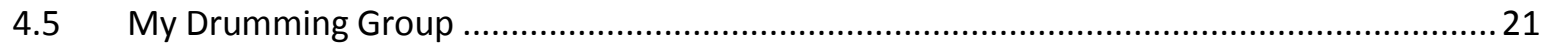

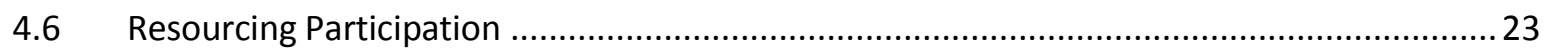

4.7 The Reflexive Cycle of Observation, Consideration and Action...........................................2 23

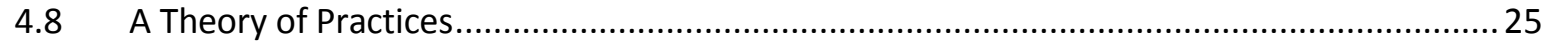

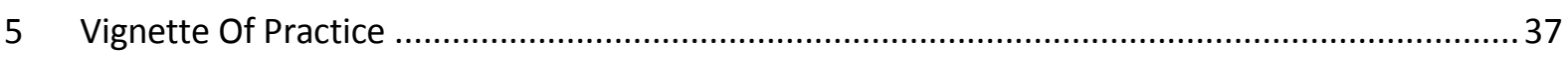




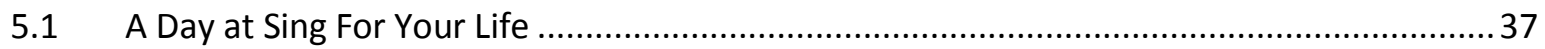

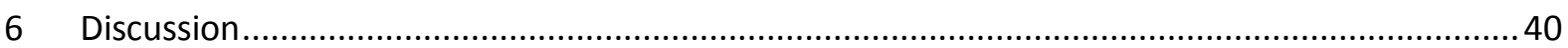

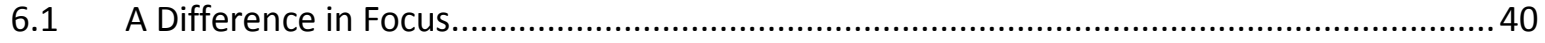

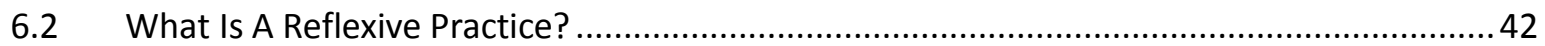

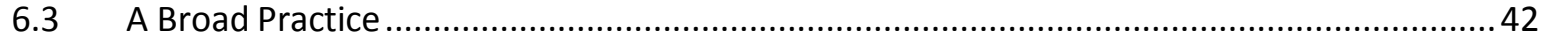

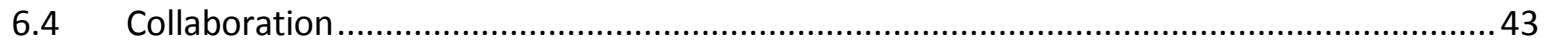

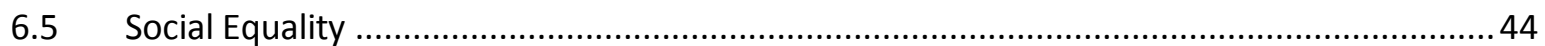

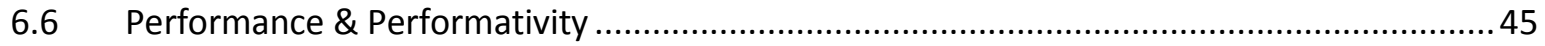

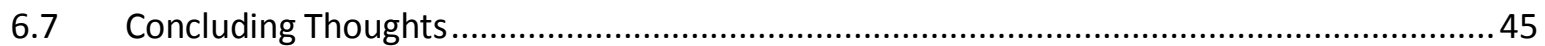

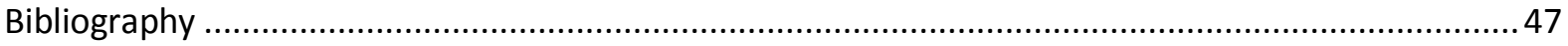

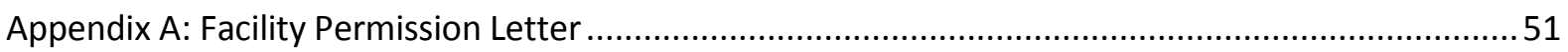

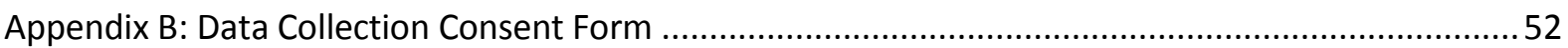

Appendix C: Illustrations of Methodology in Action- Extract from a Reflexive Journal ..........................53

Appendix D: Illustrations of Methodology in Action- Extract from Audio transcription of Meeting ...54

Appendix E: Illustrations of Methodology in Action- Extract from List of Codes...................................56

Appendix F: Illustrations of Methodology in Action - Extract from working 'Categories' file ...............58

Appendix G: Illustrations of Methodology in Action - Process vs Product- Describing the data through the lens of categories and themes as a result of using thematic analysis 
There are many heartfelt acknowledgements that need to be expressed as I complete this research report for my qualification as a music therapist.

My wife Lian has supported me in a million ways since I embarked on this journey and new chapter in my life, and without her motivation, emotional support and practical help, I struggle to imagine how I could have reached this end goal.

My grandmother Sudha, my aunt Kiran and mother Shyama were, with Lian, the most effective team of proof-readers, editors, coffee makers, motivators and planners I could ever need. They enabled the jigsaw puzzle of this exegisis to fit together in the last few weeks.

I would also like to thank my lecturers and classmates for making these past two years the most amazing learning experience I have ever been a part of, and especially to my research supervisor Dr. Daphne Rickson, whose meetings always left me feeling positive, excited and focused about my research, even when it all seemed too overwhelming.

My placement coordinator, fellow community music group members and community musicians, thank you for supporting me throughout this challenging year, and making it the enjoyable, personally stretching and memorable experience that it was.

My final thanks go to my parents, Gururaj Pagad and Shyama Narayan Pagad, who have always encouraged me to be curious, and gave me the resources and tools to be able to educate myself and follow my passions, wherever they may lead. 


\section{ETHICAL STATEMENT}

Approval was gained for this study from an ethical committee at the University of Victoria, Wellington, as part of the ethics application approved on the second of August 2011, made on behalf of students in the Master of Music Therapy Programme.

The ethics application number is HEC Southern A 11/41 


\section{INTRODUCTION}

\subsection{RESEARCH AIMS}

As part of my Master of Music Therapy programme, I was placed with a Community Music company, who ran a variety of programmes in Wellington, New Zealand. This placement gave me the opportunity to explore the realms of Community Music (CM) and Community Music Therapy (CoMT), particularly their intersections, as well as opportunities for crosspollination and mutual enrichment. It was the first placement of this kind for a New Zealand music therapy student.

My research specifically focuses on what role or roles a music therapy student can fill in a community music environment. Data was gathered from my own experiences over a continuous six-month period and subsequently analysed, with the aim of contributing to discourse on the intersections of $\mathrm{CM}$ and CoMT. The research documents my personal journey as a music therapy student situated in a community music context and using some elements of auto-ethnography.

My research question concerned my evolving role as a student music therapist, and was partially dependent upon the context in which I found myself in. As it turns out, my placement was a community music setting. I began this research study interested in understanding what it means to be a music therapist in this setting, and who I am as a music therapist.

\subsection{Personal Stance}

My interest in how community and social well-being can affect individual well-being started at a young age and has its roots in my family's emigration to New Zealand from India when I was 12 years old. This had a huge impact on me, and I started noticing things that I was completely oblivious to previously. Where I had been part of a privileged majority, and had always 'belonged', I now became very aware of a feeling of 'otherness'. As time went by I 
increasingly began to appreciate and seek out a sense of belonging, which I suddenly felt I was lacking in.

My undergraduate study in Anthropology and Psychology helped me gain a more intellectual understanding of these concepts; I recognised how much of an impact one's feeling of belonging affects their cultural identity, as well as their overall well-being. On reflection, I realised the large role music had played in my sense of belonging and in defining me as a cultural entity. At grammar school, the music department became a sort of refuge for me, a place where I was recognised, appreciated and able to meaningfully contribute. Being part of the concert band, jazz combo and other school-sponsored musical activities enabled me to make relationships and have a recognised place within the school's community.

As I became more aware of how music was helping me place myself in a social context, I further embraced this 'musical identity' I had created. I formed bands with friends, continued to pursue musical learning, joined drum circles and even grew my hair long as a sort of visual signifier of who I was. This culminated in an explicit and overt venture of joining Nga Tangata Hou, a waiata group helping 1.5 generation New Zealanders 'spread their roots' in New Zealand by engaging with Maori musical culture. Little did I realise at the time that this was my first experience of community music.

Besides the social aspect of music, I found musical activity to consistently aid my personal well-being, for example, by listening to my favourite songs I could regulate or better understand my emotional state. Daily two-hour drum-kit practice sessions became a regular routine for me between the ages of 23 and 25 , and served me as a safe space away from everybody where I completely expressed myself and stayed in the moment through practice. As I recognised and built on my improving technical skills, I was able to foster a more positive self-image of myself as somebody who could do difficult things, who could be creative, and who could work hard. One could say that my music practice was my own personal therapy.

Enrolling into the Master of Music Therapy programme and undertaking the first year of study at the New Zealand School of Music greatly expanded my knowledge about the therapeutic potential of music, as well as my own potential as a therapist. I came to 
recognise my desire to help people and serve humanity in the best way I could, and as the year progressed, I became convinced that the best way would be in the role of a music therapist. 


\subsection{COMMUNITY Music}

The roots of Community Music (CM) go back to social education programmes in the United Kingdom post World War II. These programmes evolved into the socio-cultural 'community arts movement' of the 1960s and 1970s (Skingley, Clift, Coulton, \& Rodriguez, 2011). As such, CM places importance on social equality, empowerment, activism and social change (Ansdell, 2014; Batt-Rawden \& Denora, 2005; Davidson et al., 2013; Rolvsjord, 2004; Skingley et al., 2011).

In the literature, community musicians are primarily still referred to primarily as educators; there being a focus on learning and theories of learning in the discourse around CM (Ansdell, 2005; Bailey \& Davidson, 2002; Stige, 2014; Tsiris, 2014). Parallel to this however, is a resistance against institutions and institutionalised learning (Richardson, 2013), perhaps stemming from the activist and counter-cultural roots of CM.

Various authors discuss the values and goals of CM. It seems that the discipline is a broad one, concerned with many aspects of social awareness and action. These include; dissolving traditional boundaries between 'high-brow' and 'low-brow' art, providing equal access to the arts for marginalised communities, giving those marginalised people a voice, the empowerment of individuals and groups, gaining skills, raising social awareness, building communities and social bonds, embodying and enacting cultural values, helping social reintegration, and enhancing self-growth, self-knowledge, self-esteem, as well as friendship (Ansdell, 2002; Jones, 2014; Pavlicevic \& Ansdell, 2004; Veblen, Messenger, Silverman, \& Elliott, 2013).

$\mathrm{CM}$ remains difficult to define because of its context-dependent nature. Schippers and Leigh-Bartleet (2013) note that definitions are often either too broad or too specific to contribute toward a shared understanding of what community music is. There is consensus, however, that $\mathrm{CM}$ can facilitate social and individual benefits, through promoting empowerment, equality, respect, and social connections between people (Ansdell, 2014; 
Batt-Rawden \& Denora, 2005; Davidson et al., 2013; Oosthuizen, Fouché, \& Torrance, 2007; Pavlicevic \& Ansdell, 2004; Pavlicevic \& Fouché, 2014; Rolvsjord, 2004).

It seems that the promotion of well-being on a social and cultural level is quite central to $\mathrm{CM}$, with an emphasis placed on equal access to health-promoting musical activities for marginalised and/or oppressed peoples. Davidson et al. (2013); Skingley et al. (2011) have explored how community singing for older adults can promote health, well-being and quality of life. They point to quantitative data showing that participating in community singing has been associated with fewer falls, fewer doctor visits and better mental health (although they do concede certain methodological limitations). Choir singing for the homeless has also been explored (Bailey \& Davidson, 2002; Veblen et al., 2013), and is seen to have a myriad of benefits for quality of life of the participants through mental engagement, group participation and audience-choir reciprocity. Veblen et al. (2013) also describes a case study with ethnically oppressed and/or disabled students in Serbia participating in CM programmes in order to promote social reintegration, self-esteem and 'healthy self-realisation'.

It has been noted that while this focus on health and well-being is edging into the traditional territory of music therapy (Ansdell, 2014; Tsiris, 2014), CM does not have to displace music therapy or vice versa. O'Grady and McFerran (2007a) drew a distinction in the practice of community musicians and community music therapists in their priorities as music-workers. According to them, music therapy practice follows (well-being of) the individual primarily, and the context and music secondarily; while community musicians tend to put more focus on the music itself. Furthermore, by analysing six case studies, Schippers and Leigh-Bartleet (2013) were able to identify common characteristics shared among diverse CM projects: these include structural and practical characteristics such as infrastructure, organisation and public relations/visibility; social characteristics such as relationship to place, social engagement and support/networking; and pedagogical characteristics such as dynamic music-making, engaging pedagogies/facilitation, and links to schools.

$\mathrm{CM}$ can be structured through not-for-profit organisations, incorporated or unincorporated associations, or companies limited by guarantee (Cahill, 1998). This enables community musicians to set up programmes and workshops with organisational structures, and financial security. Ansdell (2002) draws attention to some important characteristics of how 
$\mathrm{CM}$ is practiced- "Practically, there are three key characteristics of CM work: it is usually 'project work' rather than an ongoing process; it often includes performance aspects and can be user-led rather than expert-led". This approach and system allows CM groups to generate leaders over time, who are able to impart skills and knowledge, thereby facilitating the emergence of the next generation of leaders (Jones, 2014). This organisational structure is quite distinct from how music therapy practices (including CoMT) are traditionally run, i.e. through health-care services and other institutions.

\subsection{COMMUNITY MUSIC THERAPY}

Community music therapy is a growing area of work around the world. It has been conceived in the literature both as an extension of and as a reaction to previously existing music therapy theory (O'Grady \& McFerran, 2007a). Moving away from medical models of music therapy which focus on individual bodily functions, music therapists have begun to consider the ways in which communities support and challenge health and well-being. Rather than simply taking music therapy into community settings, CoMT can be seen as "extending the role, aims, and possible sites of work for music therapists" (Ansdell, 2014). One of the defining characteristics of CoMT is its focus on context, i.e. an awareness of being within a socio-cultural space, and a therapeutic practice that reflects the sociocultural context in which it is placed (Ansdell, 2002; O'Grady \& McFerran, 2007b; Stige, 2002a). Stige (2002a) takes this concept further, stating that local community is not simply the context for music therapy practice, but rather a context to be worked with. Therefore health can be viewed from a larger perspective, and health and sickness can be understood as cultural phenomena, seen in terms of an individual-in-context.

Theories of CoMT also draw on critical theory and emphasises reflexive practice, whereby a therapist's own biases, judgements, assumptions, and power relations can be brought to light and therefore aid in improving one's practice (Baines, 2013; McFerran \& Rickson, 2014; Pavlicevic, 2006; Stige, 2002b). Related to this is a strong emphasis on social health and change, and CoMT discourse includes much on how the practice can promote social justice, self-advocacy, increase social awareness and community engagement, foster a sense of belonging, and address power inequalities (Baines, 2013; Curtis, 2012; Igari, 2004; McFerran 
\& Rickson, 2014; Shiloh \& LaGasse, 2014; Vaillancourt, 2012). It is thus possible to see how CoMT is closely aligned to $\mathrm{CM}$, particularly in its goals and values. There are, however, distinctions between the disciplines. Clements-Cortes and Pearson (2014) note "One major distinction between community music and CoMT is that a trained therapist can frame community music initiatives from a clinical, therapeutic stance that places the emphasis on client-centred growth and wellness". This is contrasted by the community musician's educational and performance focus in music, with general promotion of health and wellbeing being achieved as by-products of these activities.

There is a large focus in CoMT on an ecosystem perspective on health. Stige (2002a) describes CoMT as taking place within the microsystem of an individual's life, as well as the mesosystem of the individual's communal life, and the exosystem that is the cultural and social context within which the work is being done. McFerran and Rickson (2014) place an ecological emphasis on music therapy in the schooling system, for example: establishing a healthy musical culture within a school, and innovating health-promoting musical projects that have emerged from staff or students that can benefit the whole school. ClementsCortes and Pearson (2014) similarly discuss how a CoMT practice (with an ecological view) within a hospital can have benefits for the whole institution. Rolvsjord (2013) notes that CoMT can help address health concerns on structural and political levels as well as individual levels. In his seminal 2002 paper, Ansdell conceived of an individual-communal health-care continuum, noting that a community music therapist would be able to work across these settings, affecting change from the individual level right up to the social and cultural level.

Stige and Aarø (2012) have devised the useful acronym PREPARE to characterise CoMT practice. It refers to a practice that is Participatory, Resource oriented, Ecological, Performative, Activist, Reflective, and Ethics driven. McFerran and Rickson (2014) add 'Sustainability' to this- meaning a practice that has a positive impact much further down the track than when the music therapy intervention itself ends. 


\subsection{COMmonalities, Distinctions ANd Opportunities fOR COlLABORATION}

The fields of CM and CoMT share much in common. Veblen et al. (2013) point out that the professions work with similar kinds of knowledge, and furthermore share similar goals i.e. enhancing people's self-growth, self-esteem, self-knowledge, bonds of friendship and sense of community. Lee Higgins (2012) furthermore states that CoMT, like CM, is built on an inherently participatory, performative, resource-oriented and actively reflective practice. Recent literature suggests that traditional professional boundaries that exist between $\mathrm{CM}$ and CoMT are being crossed. Tsiris (2014) notes that music therapists are increasingly including more politically and socio-culturally sensitive aspects within their work; while Ansdell (2014) finds that community musicians are edging into the territory of music therapists, working with ill and marginalised people. Some community musicians are training as music therapists in order to follow more specialised pathways in health and social care, while music therapists are also learning from community musicians' ability "to engage with the musical spirit of the age, and people's varying musical needs" (Ansdell, 2014). One might even question whether distinctions between the two fields are needed at all.

By examining the literature though, it is possible to find distinctions in the focus and skillsets of community musicians vs. community music therapists. Ansdell (2014) notes that music therapists have accumulated knowledge and experience in "working with pathology and its manifestations in the service of giving people access to musicking", which is not traditionally the territory of the community musician. Community music's focus on informal learning, and challenging socio-cultural boundaries is similarly might not be the traditional territory of the music therapist. Ansdell further asserts that the two professions have not merged and indeed should not merge as they are distinct and complementary ways of using music to help people (Ansdell, 2014).

A number of authors agree that there is a need for more dialogue between the disciplines, and that collaboration and sharing of knowledge would be enriching to both music therapy and CM (Ansdell, 2014; Stige \& Aarø, 2012; Tsiris, 2014). Jones (2014), examined how CM work (a CM group named Skiffle) could encourage health promoting behaviours, attitudes and states of being. He found that CoMT concepts such as health musicking and interaction rituals (Stige \& Aarø, 2012) allowed him to more thoroughly trace the complex relationships 
between music, culture and health, in order to theorise about Skiffle's role in the promotion of health and well-being. Lee Higgins (2012) agrees with the above authors in that there are many similarities between the approaches of CoMT and CM, both professions "seeking to reclaim music for everyday life as a central force in human culture. However, Higgins also acknowledges a deficiency of "serious" literature on CM, which inhibits an equal dialogue, deep mutual accommodation and progression between the disciplines.

Oosthuizen et al. (2007) see differences in priorities between CM and CoMT as allowing collaboration to enrich practice greatly. Their case example of community musicians and music therapists co-facilitating groups as part of the Music for Life programme with disadvantaged youth in Cape Town, South Africa demonstrates how music therapists are able to focus on group process and the well-being of individuals within the group, while community musicians push the group toward a quality musical product. In working together, these music-workers are able to focus on both sides i.e. group process and musical product, without stretching themselves too thin (Oosthuizen et al., 2007).

One particularly interesting aspect of CoMT that departs from traditional music therapy opinion is that of performance. From being seen in traditional music therapy perspectives as potentially dangerous and outside of therapeutic practice, CoMT literature acknowledges and draws attention to the therapeutic potential of public performance (Ansdell, 2005; Richardson, 2013; Stige \& Aar $\varnothing, 2012$ ). The power of performance is also of importance to $\mathrm{CM}$, and it can perhaps be argued that $\mathrm{CM}$ knowledge and the positive effects of performance have enriched CoMT. Pavlicevic and Ansdell (2004) do note a distinction however - group performance within CoMT happens as a by-product or bonus, not as a therapeutic goal, whereas performance is often a goal in itself within CM. For example, the Venezuelan Music Therapy Ensemble holds community concerts and conferences, but these are held in order to promote change and wellness by raising social awareness and stimulate community development (Richardson, 2013), not simply to showcase a musical piece, or musical talent.

The fields of CM and CoMT have many similarities, with boundaries that are sometimes difficult to distinguish. It is hoped that music therapists and other professionals from related fields will find this research useful in learning about the frameworks of CoMT and $\mathrm{CM}$, and the possibilities of collaboration and mutual enrichment of both fields. 
For this study, I undertook first-person research, which Bruscia (2005) defines as "any method in which researchers or participants gather data from themselves, using processes such as introspection, retrospection, self-perception, self-observation, self-reflection, selfinquiry, and so-forth" (Clements-Cortes \& Pearson, 2014). More specifically the research had significant elements associated with heuristic inquiry. Heuristic inquiry can be understood as a research process that uses the lived experience of the researcher as the focus of study. It is designed for the exploration and interpretation of experience, as through the process of research, the researcher grows in self-awareness and self-knowledge (Shiloh \& LaGasse, 2014).

The research methodology also incorporated elements of auto-ethnography, using "an ethnographic wide-angle lens with a focus on the social and cultural aspects of the personal" (Hamilton, Smith, \& Worthington, 2008). Auto-ethnography keeps in focus the shifting identity of the self, and enables research of the self in a broader social context (Hamilton et al., 2008; Siddique, 2011).

\subsection{THEORETICAL FRAMEWORK}

The theoretical framework of this research began from a constructivist epistemology. This brought with it a number of implications, briefly explained here: There are multiple subjective realities, which can only be studied as a whole, within their context. Objects and subjects of inquiry mutually affect one another, therefore it is impossible to distinguish between causes and effects (Clements-Cortes \& Pearson, 2014). Therefore, all inquiry is subjective and value-bound, and reveals as much about the researcher as the subject of research.

While undertaking my music work I drew from discourses on CoMT, and CM (as well as collaborations of the two). 
Theories of CoMT informed how my work as a music therapy student in a community setting could be understood. The work should be seen as situated in a cultural context, and in the service of social health goals as well as individual and group goals.

Theories of CoMT also helped illuminate important features of the CM environment so as to better understand the context within which I will work as a music therapy student.

\subsection{METHODS}

The project involved the secondary analysis of data collected over a six-month period during my placement. There were two sources of data for the research. Firstly a reflexive journal was kept during my placement as a tool to facilitate reflexive thinking about my practice as well as aid in the development of my knowledge and practice as a music therapy student. Rolvsjord (2013) state that reflexive journals and thinking aid in:

1. Revealing (personal) thoughts about the context of one's practice including the setting, the 'clients', other practitioners as well as the wider sociocultural context

1 Connecting theory and practice

1 Self-evaluation and supervision

1. Practice development

$1 \quad$ Understanding the usefulness of music therapy.

A second source of data was audio recordings of group discussions and team meetings with members of the team I worked with at my placement facility, as well as supervision meetings with my research supervisor. Informed consent was received from each participating member in these meetings and discussions, for data to be used for research purposes (see Appendix A).

These sources of data document my subjective journey of being a music therapy student entering and working in a CM setting. The data was analysed at the end of the six-month data collection phase, so that theory could be generated - not just from one instance of practice, but rather from my whole subjective experience of six months at my placement facility. 
The data I gathered was subjected to a thematic analysis, whereby recurring patterns, ideas, observations and reflections were uncovered. According to Braun and Clarke (2006), thematic analysis is a six-step process, which involves:

1. Becoming familiar with the data that has been collected

2. Generating codes that categorise the data

3. Searching for themes in these codes

4. Reviewing and modifying these initial themes

5. Defining and naming the themes that have been found

6. Producing a report to convey themes found within the data.

Thematic analysis allowed me to theorise about my journey as a music therapy student in a $\mathrm{CM}$ setting, and on how and where music therapy practice and community music practice can intersect and collaborate.

\subsection{ReSEARCH PROCESS}

The research process for this project began at the end of a six-month period of working and immersing myself in a CM setting (my placement with a Community Music company), during which data collection took place. The data was collected to inform and improve my practice. Informed consent was sought for this data to be used for research purposes (see Appendix B).

As a first step, audio recordings were transcribed to written form so that all relevant data could be analysed in the same way. After this was completed, the process of thematic analysis began. As mentioned above, this is an involved process of six steps. Through thematic analysis, it was possible to elucidate my experience of being a music therapy student in a CM setting, and to theorise about how inter-disciplinary collaboration can manifest between music therapy and CM.

This report highlights and discusses themes that emerge from my practice as a music therapy student. It refers back to previous literature, looking for links and divergences between my practice and existing theory. The auto-ethnographical narrative of my 
subjective experience at my placement facility is represented as a part of Chapter 4 , in my findings section.

\subsection{Ethical CONSiderations}

Ethical considerations for this research include ensuring that participants in recorded discussions gave their willing and informed consent for data to be used for research purposes, and that they were represented truthfully in the research. Equally important is preserving the privacy and anonymity of community music participants and other individuals included in this study. Changing and/or deleting names from the gathered data helps ensure that individuals cannot be identified.

I think it is important to note that the community musician I worked with is the spouse of the programme leader for my Master of Music Therapy programme. At the beginning of placement, my research supervisor suggested that it was important for me to be aware of these multiple relationships and to acknowledge the potential for power differentials to impact on my practice and/or my research. I wanted to continue with the arrangement because the potential for learning in an area I am passionate about seemed to outweigh the risks. Nevertheless there were periods where I felt like I was being assessed at every CM session I attended, and perhaps this contributed to my insecurities and stress during the placement. I also later found it hard to finish placement because I felt some of the work depended on my presence, and I felt obligated to continue. Overall, though, I felt my placement coordinator, music therapy programme leader and I managed to negotiate the sometimes delicate territory comfortably and naturally.

\subsection{COMmUnicating ANd DisSeminating Results}

This research is part of my Master of Music Therapy programme, and as such is submitted as a Master's thesis to the New Zealand School of Music. The thesis will be catalogued at the 
University of Victoria (Wellington) where it will be available in both physical and digital copies.

\subsection{SIGNIFICANCE OF RESEARCH}

It is hoped that this research will make a meaningful contribution to the literature regarding the evolving identity of music therapy, as well as contributing to discourse on interdisciplinary collaboration between music therapy and CM. Finally, it is hoped that the narrative of a music therapy student's subjective experiences in a CM setting will be useful to other music therapists, prospective and current students of music therapy and others working in this field, in providing a perspective on the practice and theory of CoMT and CM.

\subsection{TIMELINE}

Data was collected from February until July 2014, which served as the six-month period of practice to be analysed. From August to October 2014, audio recordings were transcribed, the data were analysed using thematic analysis. This research report was completed at the end of 2014 and submitted early in January 2015. 
These findings have been produced as part of a long process which included data collection, transcription, thematic analysis as well as multiple cycles of reflection and adjustment. An example of the process of data analysis has been provided in Appendix C-G in this report. The documents include extracts from raw data (reflexive journals and audio transcriptions) as well as extracts from the working files used to analyse the data. This illustrates the process of thematic analysis, and provides an idea as to how these findings were established.

This chapter includes a narrative description of my experience at placement accompanied by relevant themes which emerged as part of a process of thematic analysis; and secondly, a more analytical section interpreting my experience at placement both through the lens of a community musician as well as a community music therapist.

\subsection{MY PERSONAL JOURNEY AS A STUDENT MUSIC THERAPIST IN MY SECOND YEAR PLACEMENT}

This section of the findings relates to my personal journey while attending this $\mathrm{CM}$ placement as part of earning my Master of Music Therapy qualification. The findings are subjective and specific to the company I worked with as well as the groups I attended, and my own experiences. Nonetheless, it is my hope that my reflections can contribute toward a better understanding of the work of a community musician, how a CoMT perspective can frame and at times influence this work, and what $\mathrm{CM}$ and CoMT can offer to enrich each other.

Furthermore it is hoped that this account will be of use to a student music therapist or beginning community musician in a similar position to mine to learn more about the challenges, possibilities, complexities and personal development it can involve. 


\subsection{Many Roles Much Confusion}

When I began my placement, I was completely naïve and confused about what my role was going to be at my placement facility. Was I a participant, an accompanist, or a leader? What about a student, a music therapist or an apprentice community musician? Members of CM groups I attended were equally unsure of my role in their groups and would sometimes ask me about it, prompting me to explain that I was a student on placement learning about $\mathrm{CM}$ and how it relates to music therapy. I found that these discussions helped me reflect on what I my role was, and what I thought it should be.

I found it very helpful talking to my placement coordinator, being able to ask him anything I was unsure about, such as whether I was doing what I should be, and what my role entailed from his point of view. As it turned out, my placement involved me regularly shifting from one role to another, even within the same $\mathrm{CM}$ session. Within one singing group for example, I would often transition from accompanist to song-leader to participant. Furthermore, I would at times find space to approach the work as a community music therapist, helping out individuals who were having a hard time participating, discussing the history of a song, or what they enjoyed about a piece of music. While adopting the role of a participant, I would at times notice that the group leader needed support, so I would model what they needed and thus transition into more of a leadership role myself.

There was nonetheless anxiety and discomfort over feeling that I was ill equipped and did not know what I was supposed to be doing, as this excerpt from my reflexive journal illustrates:

After this I led Come Back Liza and Jambalaya. By now the group is getting more comfortable and familiar with the songs. Starting both the songs is still quite a challenge for me, and something I need to practice more. Once we were going though, it came together well and the group sang enthusiastically I thought. I need to get out of my head a little bit more when I am singing. I am constantly worrying about whether people are enjoying themselves and if I am leading and accompanying correctly.

As the months passed by, there was increased awareness about the multiple roles I inhabited at my placement, and I became more comfortable with this. My multiple roles of student, participant and leader also became more explicit to the other members of the CM 
groups I attended. Overall, my reflection is that many group members saw me as an apprentice community musician, supporting my placement coordinator in different ways. This included musical support, as well as logistical support such as helping unload a van full of drums. This apprentice-teacher relationship was helpful for me in a learning position, and while this set up an explicit power dynamic, it also made the role simpler for me in some ways. 


\subsection{FeELING OVERWHELMEd ANd BUILDING MUSICAL SKILLS}

For roughly the first six months of my placement, I felt sorely lacking in the skills I needed to effectively be a community musician, i.e. lead CM groups. This manifested itself mostly in singing groups when I began to shift from a purely accompanist role, supporting my placement coordinator, to a role as 'leader'. I was not used to having a whole group look to me for leadership in this way, as my previous placement experiences had involved much more flexible facilitation and less focus on musical accuracy and quality. Another excerpt from my reflexive journal depicts this here:

After the tea-break, I led Bob Dylan 'Blowing in the wind' and Bob Marley 'Sun is Shining'. I felt quite nervous before hand, which I often have when leading songs at Sing for your life. It is a very different experience from my previous music therapy placements, as I perceive more attention, and feel like group participants want a good musical product, and that I need to deliver a good musical product.

I was used to talking to people about what they found difficult in a piece of music rather than trying to teach them to do it better. Mistakes had previously not been something to avoid for me, but rather a starting point from which to explore new avenues with the people I worked with. With this new focus on musical accuracy I became very aware of my own mistakes and gaps in musical knowledge. My gaps in theoretical knowledge of musical harmony especially made me very self-conscious when leading singing groups, as I could not show group members harmonies they might try, or change the key of a song quickly when group members' vocal ranges did not match the key I was using.

This was somewhat exacerbated by me trying to model what I had seen my placement coordinator so effectively and seemingly effortlessly do. His extremely developed musical skill and knowledge combined with his years of experience as a community musician made it seem like it was natural for him to do what he did, and try as I might, I could not seize the group's energy and direct it towards a focused musical experience in the way he did. This in turn made me unhappy and anxious at times about how my placement was going, and whether I was 'good enough'.

Support from my visiting music therapist as well as talking with my placement coordinator helped me at this point. They encouraged me to be more patient with myself, and to try to 
focus more on what was going on in the group and stay in the moment so that I could authentically respond to the group's needs rather than always thinking about my own (lack of) ability. My placement coordinator also reassured me that I was improving, and that these skills took time to build.

I focused on building musical skills that I lacked, and I found that over the course of the year these skills slowly improved. Practice and accumulated experience helped me become more comfortable at the placement, as well as the support from group members who attended community music groups I was part of. They seemed to recognise that I was a student; still picking up some musical facilitation skills, and so supported me, encouraged me, and gave me constructive criticism. This in turn helped me better support the $\mathrm{CM}$ groups I ran and supported. These musical facilitation skills are also highly relevant for the (community) music therapist role that I intend to adopt as I embark on my career.

After leading a song or two with community singing groups in sessions during the first few months of my placement, by the fourth month I began to facilitate my own community singing group as part of the 'Sing for Your Life' initiative. I felt unprepared at the time, but when discussing this with my placement coordinator, I was told that I would never be prepared, and I had to simply do it, and pick up the know-how as I went along. I took this attitude to heart, and resolved to remain mentally strong and not become disheartened. By the end of August when I stopped collecting data for this research project, I was much more accustomed to the multiple roles I was inhabiting within the placement, and more comfortable and forgiving with myself and the skills and knowledge I needed to build, and was steadily building.

\subsection{PROVIDING MUSICAL SUPPORT}

Providing musical support for their groups tends to be one of the primary roles of the community musician. This can include anything from instrumental and/or accompaniment, to cuing group members with gestures or musical cues about transitions, beginnings and endings.

At my placement, I provided musical accompaniment to singing groups by playing my 
Darbuka (Turkish drum), especially when supporting another community musician who was leading the session with piano or guitar.

As the placement progressed and I began leading singing groups myself, a drum could not provide the harmonic containment that is very helpful, so I would play guitar for the most part in these scenarios. This helped me easily convey tempo and harmony while still leaving my voice and facial expressions free to further support individuals and sections of the group, as well as cue in transitions, beginnings and endings.

While providing musical accompaniment, my focus was on supporting the group's endeavour to reach its musical goal. This focus entailed a more educational approach than I was used to from my previous music therapy placements (discussed later in these findings), and I found this particular part of the work quite challenging.

I also supported a marimba group by holding tempo with a drum-kit. My role in this group was somewhat blurred, as I was a participant to some extent, learning songs with the group and following the lead of the facilitating community musician alongside the rest of the group. However, the reason I was part of the group, and why I was playing drum-kit was to provide a rhythmic anchor, as the group had previously had difficulty holding a steady tempo.

The implicitly framed and somewhat ambiguous nature of my role at the placement provided me with quite a challenge, and exacerbated my insecurities about my musical ability. It did however allow me to be more reflexive about the work I was doing, i.e. think about why I was at the placement, and whether my actions at the placement were fulfilling this purpose, and to constantly adjust the work and my attitude to it based on these reflections.

While I started the placement with ideas of bringing a 'community music therapy flavour' to this CM setting, the reality turned out more to be me learning about what community musicians do, and practicing 'being a community musician' a great deal of the time. 


\subsection{My DRUMMING GROUP}

Roughly six months into my placement, I was given the opportunity to start my own community drumming group. The initial plan was for me to facilitate a series of four weekly sessions, filling in for another community musician who taught weekly African drumming classes. These four weeks eventually led to a regular weekly community drumming group and culminated in filling-in for my placement coordinator to lead a full-moon drumming community drum circle at a popular local bar.

I approached the initial four week opportunity with the idea of starting a CoMT focused group, as I had been told that I could form and facilitate the group in whichever way I liked. I had the idea of inviting recent migrants to a drumming group in order to help support them to foster a sense of belonging in the local community and build relationships with other people, (which I know can be hard, from my own experience of immigrating to New Zealand). In addition, a contact had been made with a mental health service provider, with the possibility of setting up a drumming group for some of their clients.

When I began to look to the practicalities of making my group happen, I found myself facing a number of conceptual challenges for which I required help from my research supervisor. I realised as a group essentially filling in four weeks of my placement facility's 10-12 week term, at least some individuals who attended the African Rhythms Class held in previous weeks would continue to turn up for what I offered. I felt that this constrained, or at least complicated, the purpose and culture of my potential group.

This challenge lead to in-depth discussions with my research supervisor about what the purpose of my group was to be, and for what reason I chose to shape it in a certain way. We reflected that the group's identity had to reflect the intended purpose, and this included the people who attended. This led to certain theoretical musings detailed in the later section of these findings about how CoMT groups come together explicitly to achieve some health or community goal, whereas $\mathrm{CM}$ groups gather to share in a musical experience.

I decided that I could not abandon the people who had previously attended the African Rhythms class and so decided to keep the group open and inclusive, focused on the enjoyment of participating in a musical experience. This decision meant my proposed group lent itself more to a CM framework than a CoMT framework, and I still wonder about the 
possibilities if I had chosen to follow up on a CoMT focused group to the exclusion of some individuals.

In the first few weeks, I included many African rhythms in the community drumming group. As I accumulated more experience over time however, I began to use certain elements from traditional rhythms and improvise rhythms for group members to play. The focus in the group became having all members feel they were participating meaningfully (according to themselves) and so it became easier to share simplified rhythms rather than the sometimes more complex traditional rhythms.

After the first four weeks I was asked if I would like to keep a regular weekly slot going for the community drumming group. As I had come to enjoy facilitating the group, and I felt like I was learning a lot from each session, I eagerly jumped at this opportunity. While there were some weeks with very few group members, I did manage to have a few people attend regularly for some length of time, and found that bonds between group members, as well as between me (as group leader) and the group, quickly developed. We enjoyed drumming and supporting one-another to improve.

The group was inclusive, and members were non-judgmental about others' contributions. They had diverse abilities including one individual who may have been classed as having intellectual disabilities, and all were able to participate in the drumming activities. This point relates to some reflections later in these findings about 'performativity'.

My experience this year as a drum circle facilitator culminated during the last month of my placement, when I was asked to fill in for my placement coordinator as the drum circle facilitator at a local popular bar's regular full-moon drumming night. The dynamic at the bar showed me a whole new aspect to CM practice; the live public session. Whereas before I had been used to a group of people coming together in a safe and secure space to share their interest in drumming, I was now in a public space with anybody able to drop in or out according to their wish. From my perspective, this meant that I had to simplify rhythms more, as most participants had not done much drumming previously. The session was also much longer than others which meant I had to be ready with ample material, whilst simultaneously being flexible enough to be able to respond to the unpredictability of a group of 35-45 people coming together for the first time. 
The considerations about groups needing clear purpose, about a CoMT group requiring a shared need or well-being related focus to come together, and about the 'positive discrimination' that can stem from this focus are discussed later in these findings.

\subsection{RESOURCING PARTICIPATION}

There was one aspect of the work at my placement, one role I adopted, which aligned more closely to a CoMT framework than a CM one. I identified this role as 'resourcing participation', i.e. supporting individuals who were struggling with fully contributing to the musical experience. This included modelling vocal parts, showing persons ukulele chords, and in one case, supporting an individual with physical difficulties to hold the chord shapes on a ukulele while I strummed, as described here (from my reflexive journal). I went over and asked them how they were doing, did they need any help... I helped [name redacted] by placing the ukulele in her lap and showing her the $C$ chord, which was the first chord of the song we were playing. The $\mathrm{C}$ chord is pretty simple on the ukulele, requiring only one finger of the left hand. [name redacted] was able to do this but struggled with strumming with her right hand. She did manage some eventually, and strummed along on the beat for about half the song before she got tired and had to stop. She told me her fingers were paining, but thanked me for helping her out as did her husband. My rationale behind these actions was one of resourcing as well as empowerment. Once I showed an individual a chord progression for example, they would then show other members of the group the same.

\subsection{The Reflexive Cycle of Observation, Consideration and Action}

As has been discussed before, a CoMT approach seems to be a reflexive one. This means the work includes a cyclic process of planning, acting, reflecting and adjusting plans. I resolved to include this type of practice at my placement, as this was one of the main tethers I had to a CoMT perspective in the $\mathrm{CM}$ setting.

As a student researcher and practitioner, my reflexive journal allowed me to keep track of 
my thought processes about what I was doing as well as my changing perceptions about the nature of $\mathrm{CM}$ work, and how a framework focusing on well-being rather than musical experience might influence this work.

I often tried to learn about groups I was part of, ascertaining norms and reasons why people attended. Related to this were the often implicit therapeutic benefits (discussed later) and how these related to the more explicit therapeutic goals I had read about in CoMT literature. Besides this research role, I reflected on my work in order to better my practice, gaining knowledge, skills and techniques relevant to community musicians, and also (I think) to community music therapists.

\subsubsection{Professional Peer Network}

During my placement, I found a great deal of support in the sharing of resources and knowledge from other community musicians. Firstly, supporting an experienced community musician, (my placement coordinator), allowed me to learn a lot through observation. We would also have an hour every week where we would have time to talk about my progress, and anything else I needed help with at placement. I often used these opportunities to ask about techniques, songs and how my placement coordinator approached the work from a philosophical perspective, i.e. what was important about the work to him.

I also found that professional networks seem to help community musicians share resources and support the development of skills in younger and less experienced community musicians. My experience relates to attending a song leaders' symposium in May, the fourth month of my placement, where song leaders from all over the country came together to share knowledge, techniques and perspectives. More experienced song-leaders would lead short sessions, demonstrating their style of song-leading as well as sharing songs they used with their own groups. This symposium was put on by the Song Leaders' network of Aotearoa, which holds regular events such as this to promote knowledge and resource sharing, as well as building relations between New Zealand based song leaders. As a relatively inexperienced song-leader at my placement, I found these sessions to be very helpful, and was able to use songs that were shared, as well as try to model aspects of facilitation I had found effective in sessions of more experienced song-leaders. 
It seems that while $\mathrm{CM}$ does not have strict qualifications and regulations, professional bodies such as the song-leaders' network allow members of the profession to have some shared understandings and values about the work, as well as support one-another in upholding these standards. 


\subsection{A THEORY OF PRACTICES}

The theory that follows is based on my subjective experience as a student music therapist working in a CM setting. It is important to note that this is just one student's perspective, of being involved with one community music business, mostly alongside one community musician. The findings must be understood as highly situated, with limited generalizability, and should be considered in the light of the discussion that follows.

The process of unearthing findings from my secondary data of audio recordings and journaling is detailed with examples in the Appendices. It follows the format of a thematic analysis, as discussed in the methodology section of this study.

This section of the findings deals with my reflections on what a CM practice involves when regarded through a CoMT lens. This does lead to some comparisons and contrasts between the disciplines, but the goal is to enrich the understanding of both professions, and the nebulous boundaries between them.

It is important to note too, that most of my understandings about CoMT come from the literature, as I did not actively practice within a CoMT framework during my placement. I did reflect on the placement and my role in it through a CoMT lens, and this would have influenced my practice, but my activity at the placement was explicitly CM work.

\subsubsection{WHAT IS CENTRAL: THE PRACTICES OF COMT AND CM ARE BOTH CENTRED IN MUSIC AND WELL-BEING ALTHOUGH THE EMPHASES IN CM SEEMS TO BE MORE ON CREATING HIGH QUALITY MUSICAL PRODUCT, COMT IS FOCUSED ON MUSIC TO DEVELOP HEALTHY COMMUNITIES}

It is an obvious statement to say that both CoMT and $\mathrm{CM}$ are centred on music. It is however interesting to examine the similarities and differences between these disciplines, and what informs them. The boundary between CoMT and CM might be seen as between the explicit and the implicit. CoMT tends to be more explicitly people centred and implicitly music centred, while $\mathrm{CM}$ tends to be more explicitly about the music, while under the surface, often indiscernible are numerous individual and group benefits, interactions and dynamics. 
A community music therapist is interested in empowering and resourcing individuals and groups, supporting them to be part of their larger community and to support the community to better include them. While music serves as the vehicle and the means by which this is achieved, the music is not the end goal or purpose of the group.

In CM contrastingly, people come together to make music, and a quality musical experience or the expression of a quality musical product can lead to a deeper connection between group members, a greater sense of mastery, improvements in self-image, and more enjoyment in the session. Relationships are built through a musical connection in both $\mathrm{CM}$ and CoMT, but in CM this is a welcome side-effect whereas in CoMT it is often a goal or point of particular interest.

A community musician acts as an access point for musical sharing, and responds to the group's musical needs and guides the musical experience. A large part of this process is balancing challenge and success, as the goal of a CM group is to have a stimulating and diverse musical experience in which all members can meaningfully participate.

\subsubsection{GROUP IDENTITY IN COMT GROUPS SEEMS TO BE OFTEN BUILT ON EXPLICIT AIMS, WHICH RELATE TO A NEED OR SET OF NEEDS WHICH ARE SHARED AMONG MEMBERS OF A GROUP}

It seems that CoMT groups usually begin with individuals sharing a common need, and work outward from there. Groups are formed to achieve therapeutic goals related to group members' needs, and the process of identifying goals is an explicit one that is negotiated with group members.

CoMT groups are therefore likely to have strong identities that are independent of their shared musical experience. As stated before CoMT seems to be implicitly music centred, but explicitly centred on the people. This could be one of the distinguishing features of CoMT. It also seems to create a philosophical tension: on the one hand, the goal is resourcing a specific need, but on the other hand, a core value of CoMT is social equality and an antidiscriminatory practice. The very act of identifying individuals and groups to support them in resourcing their needs can lead to a form of 'positive discrimination'. 


\subsubsection{MUSIC THERAPY TRAINING AND PRACTICE INVOLVES FOLLOWING A NUMBER OF REGULATIONS AND RULES}

Music therapists undergo specialised training to gain their qualification. Furthermore music therapy has an institutionalised code of ethics that music therapists must adhere to. It is because of these thorough rules and regulations that music therapist are more able to work explicitly with marginalised and perhaps vulnerable populations within a therapeutic framework.

\subsubsection{COMT IS A REFLEXIVE PRACTICE}

Community music therapists must be reflexive about the nature of their work. Questions such as "Why am I doing this?" "What benefits does it have?" "Why do people attend this group?" can mean that a community music therapist is constantly looking under the surface of the musical experience. There seems to be a need to be thinking about the purpose of everything they do in relation to the purpose of the group. Overly supporting the group might actually undermine the group's long term goal of empowerment for example. Reflecting and critiquing their work in depth to find out what they are providing, and what is going on, allows community music therapists to identify and expose their own biases, improve their skills and knowledge as therapists, and consequently provide a better service. Being a music therapy student approaching my placement from a CoMT framework required me to be reflexive about what I was doing, and why I was doing it, and consequently adapt my practice.

\subsubsection{A COMT PRACTICE IS MORE FOCUSED ON THE GROUP'S PROCESS THAN A MUSICAL PRODUCT OR OUTCOME}

A community music therapist is interested in individual and group responses to a musical experience and what these responses say about the group's dynamic and process, and the ways in which they engage with their communities. The musical experience is guided to fulfil 
the needs of individuals and the group as a whole, in relation to their communities, as well as the needs of the community.

A community music therapist's approach to group facilitation is likely to reflect this emphasis on group process over musical product. A CoMT group is likely to be more flexible in musical content and to perhaps have less of a focus on the aesthetic value of the musical experience and skill development and/or mastery. This approach sanctions more pauses between music, more verbal interaction, and more of a collaborative style of facilitation rather than a directive one. Consequently, group members are encouraged to step into a more active role in the group, support each other, and develop deeper bonds through interpersonal interactions.

\subsubsection{COLLABORATION BETWEEN COMMUNITY MUSIC THERAPISTS AND COMMUNITY MUSICIANS CAN BE EFFECTIVE IN THE COMMUNITY, AS WELL AS ENRICHING TO BOTH DISCIPLINES}

Community music therapists are interested in collaboration. Breaking down barriers and linking discriminated, minority or disadvantaged individuals and groups with the larger community is a practical manifestation of the core values of the discipline. An example of this from my placement is a music therapist linking a group of young adults with intellectual disabilities with a community singing group I facilitated, by making contact with me, setting up their attendance to the group, driving them to the session, and then supporting their participation in the group. This music therapist could be seen to be working from a CoMT framework here.

\subsubsection{EMPOWERMENT IS A PRINCIPLE FOLLOWED BY BOTH COMT AND CM, ALBEIT, IN VARYING DEGREES AND WAYS}

Community music therapists are concerned with the empowerment of disadvantaged and oppressed individuals and groups. Within a CoMT group, members are likely to be encouraged to take ownership of and responsibility of the group's activities, as well as the choice and achievement of goals for the group. This in itself encourages an active and empowered culture within the group. To achieve this, community music therapists tend to 
be more explicit over how much responsibility they are taking over a group's goals, and exactly what the roles and responsibilities of the group are. It is likely that this would not be dictated by the community music therapist, but rather negotiated with all members of the group in order to come to a consensus.

Although observed, I perceived less of an emphasis on empowerment at my CM placement. For example group members are sometimes asked what song they would like to perform next in a singing group, or are encouraged to try and improvise harmonies and melodies in certain sections of songs.

Some group members also take it upon themselves to support the group in different ways, such as serving teas, setting up music stands and washing up dishes.

In a community drum circle, I often encouraged group members to come up with rhythms of their own, and share them with the rest of the group. This allowed group members to express themselves, as well as feel like they were making a meaningful contribution to the group. Furthermore, to hear the rest of the group play their rhythm back to them allowed group members to feel heard and acknowledged.

In my role as a music therapy student at my placement I often found myself helping individuals join in, resourcing them to participate in the CM group. Individuals might have had difficulty participating for various reasons, including physical, mental and otherwise.

\subsubsection{SOCIAL EQUALITY AS A WIDER PHILOSOPHY IS SHARED BETWEEN COMT AND CM}

CoMT and CM both share a concern for social equality. One of the primary occupations of a community music therapist seems to be to give a voice and platform for expression, for those without one. CoMT focuses on the individual and community, seeking to resource them to achieve their goals and/or meet their needs through music as well as other means.

$\mathrm{CM}$ on the other hand often addresses issues of social equality through musical expression. This could include singing socially relevant songs, singing at events to raise awareness of specific issues, and bringing communities together through music. While both disciplines 
hold social equality as a high priority, the way they go about achieving it differs. CM's approach to social equality is perhaps less personal and more abstract than CoMT.

\subsubsection{PERFORMANCE AND PERFORMATIVITY IN A GROUP SETTING CAN BE VERY BENEFICIAL TO INDIVIDUALS AND COMMUNITIES}

Performativity has been discussed in the literature about CoMT; and I have had similar ideas about what I have observed at my CM placement. Participants coming to CM groups leave their everyday social identities behind when entering a session, and take on a new musical identity. This can mean leaving behind social identities defined by disability, race, gender etc. and embodying an identity that belongs and contributes equally with the rest of the group. One woman who attends a singing group at my placement shared with me that coming to the group allowed her to feel the same as everybody else forget about her illness and disability (she lives with Multiples Sclerosis (MS)). When engaged in group singing each week, she assumed her role as a singer - just the same as all the other singers in the group, and left behind her role as a person with a disability.

This is an example of how performativity may not be explicit in CM as it is in CoMT, but it is very much in effect. It could apply to any individual in a minority or oppressed group. Public performance takes this idea of performativity further, by allowing individuals to not only showcase their new identities and roles to each other, but also to society at large. This not only helps them, but can influence societal norms, and how society perceives and judges different people.

\subsubsection{SEEMS TO ENCOURAGE A MORE DIRECTIVE STYLE OF GROUP FACILITATION, PERHAPS RELATING TO ITS EDUCATIONAL ROOTS.}

The approach to facilitation in CM seems to be generally more directive than in CoMT. This seems likely related to the fact that community musicians are concerned with teaching musical skills and songs to participants as one of their primary roles. A community musician also has a responsibility over the group's musical outcome, perhaps more so than a 
community music therapist does. This is partly a consequence of a musical product being more central to the purpose of a CM group than a CoMT group.

A community musician's musical facilitation skills are fundamental to the experience of group members in a session. In a singing group for example, a community musician must have the skills involved in effective song-leading. This includes correctly calling people in at the start of a song, cueing them at important transitions, as well as accompanying and musically supporting the group. Musical facilitation skills are also important when balancing challenge (stimulation) and success (participation) in a CM group.

As the community musician is often the point of focus in CM groups, they can be a representation of the group's identity. A community musician is comfortable in the role of a leader and teacher, and with clear distinctions between leaders and group members. These clear distinctions can make the group easier to manage, as well as musical skills and songs easier to teach. On the other hand, these interactions can set up power hierarchies between leader and group member, which can serve to disempower group members if exacerbated. It is up to the individual community musician to make sure they manage this tendency. Nonmusical interactions on a more equal person-to-person level can help minimise these power relations. These include socialising before and after sessions, tea breaks, shared lunches on certain occasions, as well as end of year or post performance get-togethers.

Based on the literature reviewed, the facilitation style in CoMT groups seems to be more flexible and less directive. Community music therapists seem to be less focused on teaching and working towards an aesthetically impressive musical product than with achieving individual, group, and social goals related to wellbeing.

From a community music therapist's point of view, it is important to be reflexive about the nature and effects of all interactions and relationships in a music group. These interactions should ideally contribute toward empowering group members, and helping resource them to achieve their group's goals. 


\subsubsection{GROUPS COME TOGETHER BECAUSE OF A SHARED INTEREST, WHICH DEFINES THE GROUP'S IDENTITY AND CULTURE}

People attend CM groups because of a shared interest, as opposed to CoMT where groups come together because of a shared need. As a consequence of this, CM groups are made of up diverse people with diverse needs. People with different experiences come along to CM groups for different reasons.

At times, group members take a more assertive role in a $\mathrm{CM}$ session, making their musical wants and needs known. For example, if a song's range is too high/low for some members in a community singing group, they are vocal about this and let the song-leader know. This breaks them out of their typically more passive role. Group members sometimes also instigate initiatives they are interested in. A number of members in a singing group I was part of were interested in playing the ukulele, which led to ukulele playing and some teaching to be incorporated into each week's session. These group initiatives serve to empower group members and give them more of a sense of ownership over the group. Having such diverse groups does bring up some challenges for the community musician too. During the aforementioned ukulele teaching in the singing group, there have been times when non ukulele playing singers in the group felt left out and became irritated, and spoke out, for example "This is a singing group!" This point leads back to the purpose of a CM group. It is explicitly for singing that people come to a community singing group, and this can make it challenging for a community musician to facilitate groups in as flexible a way as a community music therapist might.

\subsubsection{GROUPS TEND TO HAVE AN EDUCATIONAL OR SKILL DEVELOPMENT ASPECT}

Learning and skill development are often part of a CM group's purpose, although the educational emphasis in a community music group can vary. Some groups emphasise learning and practicing vocal skills, while others teach drumming skills, or other instrumental skills and musical knowledge. The community musician needs to be clear and instructive in his/her approach, which affects the type of facilitation/leadership style. Teaching relates to achieving a better musical product, and as a group practices and builds 
their skills by being taught by the community musician, their musical product improves, which can then have many other benefits

\subsubsection{THERE ARE MANY IMPLICIT BENEFITS THAT ARE EXPERIENCED AS A CONSEQUENCE OF ATTENDING CM GROUPS}

Many of the benefits to individuals and groups in $\mathrm{CM}$ besides the acquiring of musical skills and producing a musical product are often implicit and not the stated purpose of the group. In fact, community musicians may feel ethically obliged to keep considerations of therapeutic and health-type benefits to a very superficial level, due to their focus on music, and type of training. Benefits such as a sense of achievement, improved self-worth through mastery, forging of relationships, being able to express oneself, and a feeling of belonging, community and solidarity with peers in a community group are no doubt present in the CM setting, but they are not necessarily the focus when a community musician plans and executes his/her work. Much of the relationship building, socialising and other aspects unrelated to the production of a musical product occur before, after and during breaks in community music sessions. The tea break is the one explicit point where group members are 'meant' to socialise, although a lot of this also occurs when unpacking and packing away instruments, and conducting other logistical tasks.

\subsubsection{THERE IS A GREATER EMPHASIS ON MUSICAL PRODUCT IN CM}

A common musical goal is what ties a CM group together. A musical product is the one explicit outcome from a CM session, and the type of musical experience goes a long way to defining the identity of the CM group. The musical experience is what is advertised when $\mathrm{CM}$ is being promoted, so this is the purpose when the group is together.

A community musician places more emphasis on the musical product than a community music therapist might, although this is not to say that the musical product is the only thing considered by a community musician. There is consequently a greater emphasis on musical accuracy, and the community musician has focus and responsibility for the musical value of 
what is being created. This means that a group's process to attain a musical product, and the needs of individuals in the group become a secondary priority to this. For this reason, newcomers to a CM group might feel isolated, especially if they do not yet have the skills or experience to musically participate in the group.

\subsubsection{A SHARED MUSICAL EXPERIENCE IS CENTRAL TO THE EXPERIENCE OF CM, AS WELL AS COMT}

Members of $\mathrm{CM}$ groups have not very much in common other than the shared musical interest which is related to the purpose of the group. A community musician has to establish a shared musical experience to bring a CM group together, so that everybody is "brought onto the same wavelength' so to speak. This is often done at the start of a CM session, and depending on the type of musical experience, this can be done in different ways. A drumming session might involve everybody playing a rumble to start off, or some sort of simple steady beat. In a singing group, establishing a shared musical experience seems often to mean singing songs that are familiar to the whole group, that the group feels it has some ownership and mastery over, because of having done it before.

This can mean that new CM groups are special challenges to the community musician, as group members are sometimes cautious and hesitant in fully sharing themselves due to a lack of trust in each other and the community musician. Without establishing a shared musical experience, (or history of a shared musical experience), bonds between group members could be weaker. While this can also be true for CoMT, the shared need that bonds CoMT groups together can mean that they might experience this to a smaller degree.

\subsubsection{PRACTICE CAN BE UNDERSTOOD AS BEING INWARD FOCUSED WHEN COMPARED WITH COMT}

CM groups have an inward focus, in contrast to a CoMT group's outward focus. This means that the session itself, and what the community musician is teaching/sharing is likely to be of greater importance in $\mathrm{CM}$. Other than public performances, $\mathrm{CM}$ groups tend not to be concerned with what goes on outside the walls of the session. 
There is also a perception that a bigger group leads to a better musical experience. A bigger group in a CM session allows for a stronger musical expression from the group, and less individual responsibility on the musical product for each member.

For a community musician, larger group numbers also means more financial viability, which is always a consideration. Furthermore, the community musician's role is to resource their community with music, thus the more people are part of $\mathrm{CM}$ groups, the more visible the music becomes, and the more people (directly and indirectly) share in the musical experience. In addition to public performance, flyers, posters, social media and other kinds of advertising are therefore used to raise the profile and visibility of $\mathrm{CM}$ groups.

\subsubsection{PeRSONAL BONDS AND FEELINGS OF SOLIDARITY ARE OFTEN FORMED AND CULTIVATED AMONG MEMBERS OF CM GROUPS}

Being part of a CM group can lead to a strong feeling of togetherness and solidarity over time. This could be due to a number of reasons. Firstly, the challenge of learning difficult to master musical skills, as well as working together towards a common goal, a public performance for example, can grow deep bonds between group members. Group members can sometimes take on more of the responsibility in supporting each other, which could be seen as the traditional role of a community music therapist. This includes both musical support (sharing lyrics, helping one-another with melodies) and non-musical support (sharing advice, offering car rides, developing friendships).

Group members not only support one-another, but also the community musician. This could include offering feedback and emotional support for a learning community musician, or logistical support such as helping pack/unpack instruments. The group members are in effect supporting the community musician to support the group, all in aid of the group's overall purpose of sharing a musical experience. All of these characteristics lead to a CM group feeling like a team of people, working together to achieve a goal that everybody is invested in. 


\subsubsection{HAS ROOTS IN ACTIVIST AND ANTI-INSTITUTIONAL MOVEMENTS, AND THUS TENDS TO HAVE LESS FORMALISED CODES OF PRACTICE COMPARED WITH COMT}

CM does not tend to have formalised codes of practice in the way that music therapy does. It involves more of a 'learning on the job' approach than a specialised training approach. Community musicians do not have an explicit and regulated ethical obligation to keep individuals in their group safe and supported. However, they do follow their personal moral compass, which can sometimes mean a more flexible practice, as well as perhaps a more ethically relevant one, as each situation is considered and reflected upon separately. In general however, community music therapists could be likely to invest more thought and effort into ethical concerns and following ethical codes of practice, as this is the nature of their work.

\subsubsection{BOUNDARIES BETWEEN COMT AND CM ARE NEBULOUS AND THEIR TERRITORIES OVERLAP}

There are no clear cut boundaries between CoMT and CM, and the distinctions between the disciplines are blurred. Approaches and techniques are often shared, although the overall goal and purpose are different. Aspects like positive reinforcement and encouragement that could be seen as music therapy 'techniques' are also used in CM. Individual styles of facilitation can really dictate what happens (and why) in a CM or CoMT group-Superficially, both disciplines might seem similar, but an interesting way to look at it is that the two disciplines are enmeshed, like two circles that overlap.

\subsubsection{A COMMUnity Music Therapy to COMMUNITY MUSIC CONTINUUM}

This continuum from Community Music Therapy to Community Music (Fig. 1) was developed by my research supervisor and myself. It serves to draw out some of the distinctions and ambiguous boundaries between the disciplines of CoMT and CM, as well as perhaps some of the relationships between different aspects of the work. 


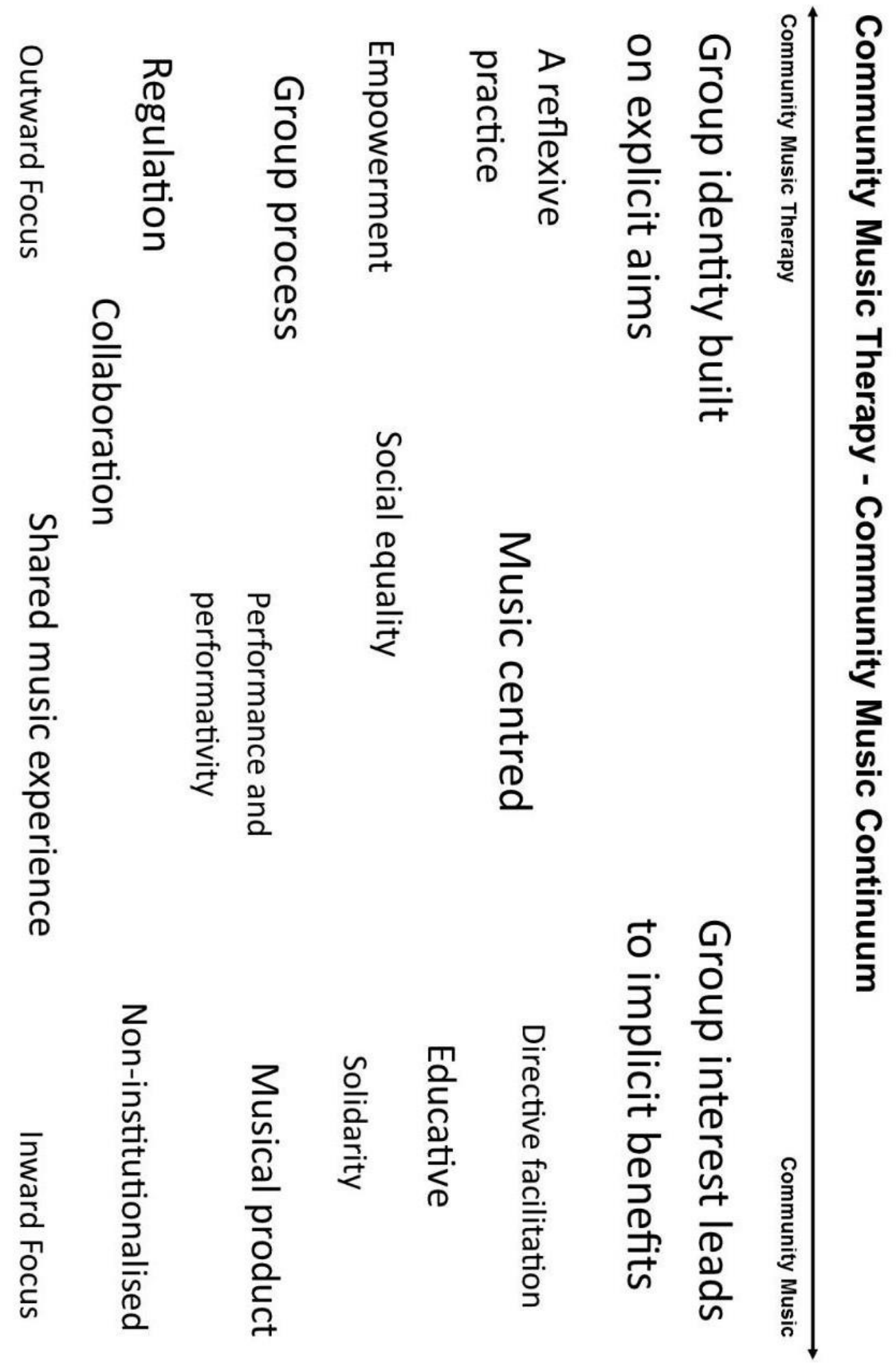

Figure 1: A Community Music Therapy-Community Music Continuum 
This 'clinical vignette' is intended to be a snapshot of one community music session which I facilitated during my placement. It is more a vivid description than a theory, although reflections on the work are also included to enrich the description and link it with the findings and discussion sections of this research.

The vignette is based on an entry in my reflexive journal from June, around midway through my placement. I have edited some comments to further explain certain concepts or issues, and tried for the most part not to change the flavour of the original entry. It is important to note that all community music participants have had their names changed to preserve anonymity and ensure privacy as discussed in my ethical statement.

\subsection{A DAY AT SING For YOUR LIFE}

"I arrived early again today, after having some lunch after Karori. I was actually feeling a little fatigued for some reason, perhaps it was mental exhaustion from the Karori session and thinking about what I would be doing for this one."

"The volunteer member of the group, Nola, who helps with administrative and logistical issues arrived at around $1 \mathrm{pm}$, and we had a quick chat while she put the milk in the fridge and helped me set up the room. It is really nice having her helping me out with this group".

Group members sometimes take on greater responsibilities and roles than the average participant. They can help a community musician in many aspects of the work, including easing mental stress. I would often confide in my volunteer helper my fears and insecurities, and she would share her (very helpful) perspective, allowing me to approach the work with renewed motivation.

"By $1.15 \mathrm{pm}$, most of the group had arrived, although Amy was a little late. We went through some warm-ups which I had seen my placement coordinator use today with the other 
group, such as 'the motorboat' to loosen up lips. I still feel very self-conscious with this group, as I feel that everybody is looking to me to give them a good musical experience, and that I may be letting them down sometimes. When we were doing some of the warm-up songs, my nervousness translated into a weak voice, and in a group like this, the facilitator really needs to have a strong voice to give the music a strong foundation and make the group feel safe. We got through the songs nonetheless, and had a chat about the song Long John and what the story behind it might be".

Coming to terms with the reality of running community music groups took quite some time. My musical skills, self-confidence in group settings and clarity of communication that are required to be a more effective community musician were always being tested and worked on. There were a number of times during my placement, while song-leading or facilitating a community drum circle, I would feel overwhelmed on the inside, but would still have to focus on supporting the group to achieve their musical goal.

"We then sang Come Back Liza and Jambalaya, two simple songs that I have been using with various individuals and groups for some time. They are my 'safe songs', my fallbacks when I am not feeling comfortable or confident. I thought we sang them quite well, although I had to go over some lyrics of Jambalaya, as I had last week. I was expecting this though".

Establishing and keeping alive a shared musical experience is the job of the community musician. I remember my placement coordinator talking about a sense of flow, and I think this is a very important aspect of the work.

"After a few more songs we had a tea break during which Matilda and Wanda talked about the swimming they had done earlier today and everybody generally updated each other on what they had been up to. I really enjoy this aspect of the group; and I feel a small group, as well as perhaps my style of facilitation allows more of this interpersonal interaction to take place".

The style of facilitation I employed in community music groups was very much informed by my music therapy training. I always perceived my placement coordinator to have a more 
focused and educational style of facilitation than I did, which I think is more effective in a community music setting. My own flexible and less outcome focused style of facilitation perhaps led to sessions with a different flavour, and I cannot judge one style to be 'better' than the other. My group's purpose was more open, to be set by the needs of the group members who attended. This contrasted with the singing groups I attended as an accompanist or participant, where the focus was already on the musical outcomes and an enjoyable musical experience.

I suspect that my community music placement has influenced my style of working too. Perhaps this means that I will be less flexible and more structured in music therapy sessions I facilitate, and again it is impossible to judge these subjective aspects as better or worse. 
In this concluding chapter, I will attempt to test my theory detailed in Chapter 4, against the literature. I will also summarize other aspects or issues of the placement that were minor or irrelevant to the research question, but are nonetheless important when discussing this kind of work.

\subsection{A DifFERENCE IN FoCUS}

Looking back at the picture I have painted through analysing my data, I can say that my CM groups shared a focus on having an enjoyable shared musical experience and on developing musical repertoire and skill. This is not to say that a myriad of other group processes were not occurring under the visible surface. Community musicians are perhaps not interested in further developing a theory of their work, rather focusing their energy on being able to create and support the best musical experience they can.

I remember noting a number of implicit benefits which could be framed as therapeutic for individuals and groups. I have illustrated some of these benefits in my findings section, such as discussing empowerment, feelings of solidarity, as well as describing an illustration of performativity aiding individuals improve their well-being.

I state in my findings that CoMT groups appear to be built on explicit aims, which are related to a shared need among members of the group. I also contrast this with what I define as 'community music practice', where groups come together for a shared musical interest, and needs may or may not be shared among group members.

O'Grady (2004) wrote that for a community music therapist, both the music and therapeutic concerns influence the aims of the group, and while music is important in defining roles and identities, a therapeutic framework is helpful in defining outcomes for the group. This hints at the values that are core to CoMT i.e. therapeutic goals using the cultural medium of music. 
There are some studies into the benefits of being part of a CM group, and these illustrate the point that the boundaries between CoMT and $\mathrm{CM}$ are not well defined and solid, but rather, both share common territory or aspects to them. Veblen et al. (2013) for example discusses how CM can provide a means for "healthy self-realization", as well as social reintegration, and uses examples from Serbia, the United States of America, as well as South Africa. These are very familiar terms to a music therapist, and this sort of CM work could be framed successfully within CoMT.

Through discussions with my research supervisor, I got a sense of CoMT groups being outwardly focused, using their time and effort to affect change both within and outside with wider society. We contrasted this with the conception of an inward focused practice in CM, where the experience is primarily focused on promoting, supporting and enjoying the musical experience, while issues like social and/or individual change are secondary or tertiary goals for group members.

O'Grady and McFerran (2007a) observe that while community musicians and community music therapists are both music-workers, their priorities differ. CoMT follows where the individual within the context leads primarily and the music secondarily. The music therapist considers the aesthetic value of music only inasmuch as it serves participant well-being. They go on to say that a community musician in contrast might follow the music over the individual at times, therefore prioritizing aesthetic value for its own sake rather than for the sake of individual or social change.

O'Grady and McFerran's Health-care Continuum (O'Grady \& McFerran, 2007b) was a very useful tool for me to conceive the professional boundaries between CM and CoMT. With the help of my research supervisor, I was able to construct a more theoretical continuum (See Fig. 1) from CM to CoMT using the data I collected for this research study.

Pavlicevic and Ansdell (2004) reiterate the differences in focus between CM and CoMT. They state that in $\mathrm{CM}$, performance and musical product are the driving force pushing the group forward, whereas in CoMT, group performances are a by-product of the therapeutic process, which may be bonuses, but are not the goal of those groups. 


\subsection{What Is A Reflexive Practice?}

I committed to approaching my work in a reflexive way when I designed my research question to use a CoMT lens when approaching my work at placement. This meant asking constant questions of my work, and adapting and changing what I did day-to-day based on what I found. I found that his approach meant I really had to justify to myself why I would employ a technique or make a decision, and consider it in context of the purpose, or goal of the group I was part of.

O'Grady and McFerran (2007a) discuss the tendency in CoMT to challenge convention, and evaluate assumptions and procedures often taken for granted. This is important when one conceives CoMT practice as an anti-oppressive one, as Baines (2013) does. To address power inequalities based on difference, one needs to keep in mind one's own power relations, and test every decision against a set of professional or private views.

McFerran and Rickson (2014) who explored CoMT in a school i.e. an institutional setting, found that a reflexive practice was crucial to their approach. They described a cyclical structure containing both reflection and action. This approach was detailed by Stige and Aarø (2012), who listed a reflective practice as one of the five key features of CoMT. They report that Even Ruud defined CoMT as "the reflexive use of performance-based music therapy within a systemic perspective (Ruud, 2004).

\subsection{A BROAd PRACTICE}

My placement could be called a broad practice when I look back at it in retrospect. It involved many roles to fill including group participant, musical accompanist, community musician, apprentice, student, and at times, community music therapist. There were also many different skills to use in complementary ways, some of which I needed to improve or learn. I continue to build my knowledge of these skills, but I think it is important for any entry level community musician, or music therapist or student beginning work in a community based setting to know that one must always be ready to leave behind preconceived ideas of their role when the context makes demands of them. 
An illustration of this is the instance when as part of my placement, I was involved in a community musical theatre project, in spite of the fact that I had never done any theatrical work before. The community musician, who was my placement coordinator, was able to effectively support three groups of singers.

\subsection{COLLABORATION}

There are some entries in my reflexive journal about collaborations between community music therapists and community musicians. In this instance, I filled the role of a community musician running a singing group while collaborating with a music therapist whose work I theorise with a CoMT lens. His job was resourcing a group of young people and adults with intellectual disabilities as part of a community initiated programme to provide services for people with intellectual disabilities. This involved having music sessions with the group as well as supporting them to attend CM groups, one of which was my weekly singing group. There are two entries from different days about this type of collaboration and both seem to be positive experiences for all parties involved, the community group of singers I met with every week, as well as the other individuals attending through their community service provider. A new culture had to be negotiated for this new group.

Oosthuizen et al. (2007) discuss collaborative work between music therapists and community musicians in developing a South African CoMT project. In their descriptions, the music therapists often helped individuals out, particularly those struggling with musical skills or other challenges to their participation in community music (therapy) groups. The community musicians would be more focused on the group as a whole, its dynamic and the goals and outcomes it is striving for.

O'Grady and McFerran (2007b) have sought to unite the two disciplines at a theoretical level, using their tool the Health-Care Continuum. They found that the accumulation of a body of music therapy skills, knowledge and expertise could be as useful to a community musician as to a community music therapist, working at opposite ends of the Health-Care Continuum. 
Ansdell (2014) shares this opinion, stating that CoMT does not have to displace Music Therapy or CM, but that each discipline can seek to collaborate and enrich one-another's practice.

Veblen et al. (2013) state that community musicians and music therapists often integrate similar kinds of knowledge, and that they even share similar goals, which is an area of the work where I have theorised that the two disciplines have solid boundaries and differences.

\subsection{SOCIAL Equality}

Tsiris (2014) notes that CoMT and CM both emphasise a socio-cultural and context-sensitive approach, and this sentiment is echoed by a number of other authors. Baines (2013); Curtis (2012); Igari (2004); Richardson (2013); Shiloh and LaGasse (2014); Vaillancourt (2012) each discuss aspects of music therapy theory and practice which are related to a socially ethical and active way of working, and illustrate some examples of music therapy being used to affect social change and challenge oppressive cultural attitudes and behaviours in different contexts.

At my placement, social issues were present, but were interacted within a more abstract and less personal way, I thought. For example I remember singing a 'fair-trade banana' song in a singing group early in my placement. The song raised important issues and awareness about making socially conscious economic choices for the members who sang, and perhaps prompted them to make changes in their own lives.

Rimmer (2012) finds that giving 'at risk' youth the powers of choice and participation in a CM group, allows them to experience many positive benefits, while van Eck (2014) asserts that a community musician's job is to enable and empower. This approach of empowerment is also discussed in the CoMT literature. Oosthuizen et al. (2007) found that performance can give hope to communities by showcasing skill and empowerment, while Rolvsjord (2004) discusses how a mental health practice using an empowerment philosophy can contribute to the discourse around CoMT. 


\subsection{Performance \& PeRFormativity}

My experience and understanding of performativity was discussed in the findings section of this report. Ansdell (2005) also discusses the idea of performativity, as do a number of other authors. Ansdell (2005) discusses performativity in terms of how one can 'perform beyond themselves', surpass their culturally, physically, mentally, or emotionally imposed limits. He goes on to say that performance plays a role in generating mutual respect. Respect must be performed according to Ansdell, and the act of performing a practiced and impressive piece of music can serve to challenge the traditional power dynamics between health workers and patients. 'Taking each other seriously' as a concept could be lived, and giving performances can have positive and healthy connotations relating to an innate mode of musicking. We are after all cultural beings and performing is a vital human cultural behaviour.

These ideas about the importance of performance echo what I have observed at my placement this year. An illustration of this idea would be the woman with MS describing herself transcending her illness and disability, "feeling like everyone else in the group" when singing in a weekly community singing group. It is important to note that performativity seemed to work at an implicit level in the CM groups I attended, whereas CoMT practice lies within a framework of reflexive work. This concept seems more explicitly considered and explored through scientific reports and studies, such as Oosthuizen et al. (2007) debating the value of performance within CoMT and CM work. They state that in CoMT, performance can be a valuable part of the therapeutic process, providing a medium through which clients can explore relationships and affirm their identities within the community. While something along the same lines is likely to also be occurring in $\mathrm{CM}$ groups, there is not as much focus on these issues as on the musical product and experience.

\subsection{CONCLUDING THOUGHTS}

By setting a research question i.e. what is the role of a student music therapist in a $\mathrm{cm}$ setting, and following a research plan to answer the question, I found that CM and CoMT are disciplines with many similarities in appearance and structure which tend to diverge when looking at goals and overall objectives and foci. I also found that using a reflexive 
approach to my practice, which was informed by a CoMT framework, required me to regularly question the reasoning and philosophy behind my CM work, which was relevant as a researcher as well as an improving $\mathrm{CM}$ practitioner and music therapy student.

My practice was a broad one, and involved regular transitions in role, often within the same session. Some roles which I embodied include participant, accompanist, song-leader, community music therapist, and drum circle facilitator.

The literature describes examples of collaboration between community music therapists and community musicians. The findings suggest collaboration between community music therapists and community musicians can benefit both professionals.

Social equality seems to be commonly shared value between $\mathrm{CM}$ and CoMT. The ways in which this value is acted upon was also explored. Performance and performativity as aspects of group behaviour was found to be mentioned in the literature, and again this was mentioned in the data collected as part of my placement. 
Ansdell, G. (2002). Community Music Therapy \& The Winds of Change. Voices: A World Forum for Music Therapy, 2(2). https://normt.uib.no/index.php/voices/article/view/83/65

Ansdell, G. (2005). Being Who You Aren't; Doing What You Can't: Community Music Therapy \& the Paradoxes of Performance. Voices: A World Forum for Music Therapy, 5(3).

Ansdell, G. (2014). Revisiting 'Community music therapy and the winds of change'; (2002): An original article and a retrospective evaluation. International Journal of Community Music, 7(1), 1145.

Bailey, B. A., \& Davidson, J. W. (2002). Adaptive Characteristics of Group Singing: Perceptions from Members of a Choir For Homeless Men. Musicae Scientiae, 6(2), 221-256. doi: $10.1177 / 102986490200600206$

Baines, S. (2013). Music therapy as an Anti-Oppressive Practice. The Arts in Psychotherapy, 40(1), 15. doi: http://dx.doi.org/10.1016/j.aip.2012.09.003

Batt-Rawden, K., \& Denora, T. (2005). Music and informal learning in everyday life. Music Education Research, 7(3), 289-304. doi: 10.1080/14613800500324507

Braun, V., \& Clarke, V. (2006). Using thematic analysis in Psychology. Qualitative Research in Psychology, 3(2), 77-101.

Bruscia, K. E. (2005). Designing Qualitative Research. In B. Wheeler (Ed.), Music Therapy Research (Second ed.): Barcelona Publishers.

Cahill, A. (1998). The community music handbook: A practical guide to developing music projects and organisations: Currency Press and Music Council of Australia.

Clements-Cortes, A., \& Pearson, S. (2014). Discovering community music therapy in practice: Case reports from two Ontario hospitals. International Journal of Community Music, 7(1), 93-111.

Curtis, S. L. (2012). Music therapy and social justice: A personal journey. The Arts in Psychotherapy, 39(3), 209-213. doi: 10.1016/j.aip.2011.12.004

Davidson, J. W., McNamara, B., Rosenwax, L., Lange, A., Jenkins, S., \& Lewin, G. (2013). Evaluating the potential of group singing to enhance the well-being of older people. Australasian Journal on Ageing. 
Hamilton, M. L., Smith, L., \& Worthington, K. (2008). Fitting the Methodology with the Research: An exploration of narrative, self-study and auto-ethnography. Studying Teacher Education: Journal of Self-Study of Teacher Education Practices, 4(1), 17-28. doi: 10.1080/17425960801976321

Higgins, L. (2012). Community Music In Theory And In Practice: New York: Oxford Univserity Press, 2012

Igari, Y. (2004). 'Music therapy is changing' and so am I: Reconstructing the identity of a music therapist. Voices: A World Forum for Music Therapy, 4(3).

Jones, J. A. (2014). Health musicking in Skiffle Steel Orchestra: Thoughts on collaboration between community music therapy and medical ethnomusicology. International Journal of Community Music, 7(1), 129-144

McFerran, K. S., \& Rickson, D. (2014). Community music therapy in schools: Realigning with the needs of contemporary students, staff and systems. International Journal of Community Music, 7(1), 75-92.

O'Grady, L. (2004). What is the experience of a community musician who is also a music therapist? Voices: A World Forum for Music Therapy, 4(2).

O'Grady, L., \& McFerran, K. (2007a). Community music therapy and its relationship to community music: where does it end? Nordic Journal of Music Therapy, 16(1), 14-26.

O'Grady, L., \& McFerran, K. (2007b). Uniting the Work of Community Musicians and Music Therapists through the Health-Care Continuum: A Grounded Theory Analysis. Australian Journal of Music Therapy, 18, 62-86.

Oosthuizen, H., Fouché, S., \& Torrance, K. (2007). Collaborative work: Negotiations between music therapists and community musicians in the development of a South African community music therapy project. Voices: A World Forum for Music Therapy, 7(3).

Pavlicevic, M. (2006). Worksongs, Playsongs: Communication, Collaboration, Culture, and Community. Australian Journal of Music Therapy, 17, 85-99.

Pavlicevic, M., \& Ansdell, G. (2004). Community music therapy: Jessica Kingsley Publishers. Pavlicevic, M., \& Fouché, S. (2014). Reflections from the market place - Community music therapy in context. International Journal of Community Music, 7(1), 57-74.

Richardson, D. E. (2013). The Venezuelan Music Therapy Ensemble (ENVEMUST). Voices: A World Forum for Music Therapy, 13(2).

Rimmer, M. (2012). The participation and decision making of 'at risk'youth in community music 
projects: an exploration of three case studies. Journal of Youth Studies, 15(3), 329-350.

Rolvsjord, R. (2004). Therapy as empowerment: Clinical and political implications of empowerment philosophy in mental health practises of music therapy. Nordic Journal of Music Therapy, 13(2), 99111.

Rolvsjord, R. (2013). Music therapy in everyday life, with" the organ as the third therapist". Centre for Music and Health Publication Series, 6.

Schippers, H., \& Leigh-Bartleet, B. (2013). The nine domains of community music: Exploring the crossroads of formal and informal music education. International Journal of Music Education, 31(4), 454-471.

Shiloh, C. J., \& LaGasse, A. B. (2014). Sensory Friendly Concerts: A community music therapy initiative to promote Neurodiversity. International Journal of Community Music, 7(1), 113-128.

Siddique, S. (2011). Being in-between: The relevance of ethnography and auto-ethnography for psychotherapy research. Counselling \& Psychotherapy Research, 11(4), 310-316. doi: $10.1080 / 14733145.2010 .533779$

Skingley, A., Clift, S. M., Coulton, S. P., \& Rodriguez, J. (2011). The effectiveness and costeffectiveness of a participative community singing programme as a health promotion initiative for older people: protocol for a randomised controlled trial. BMC Public Health, 11(1), 142.

Stige, B. (2002a). Culture-centered music therapy: Barcelona Publishers.

Stige, B. (2002b). The relentless roots of community music therapy. Voices: A World Forum for Music Therapy, 2(3).

Stige, B. (2014). Community music therapy and the process of learning about and struggling for openness. International Journal of Community Music, 7(1), 47-55.

Stige, B., \& Aarø, L. E. (2012). Invitation to community music therapy: New York : Routledge, 2012.

Tsiris, G. (2014). Community music therapy: Controversies, synergies and ways forward. International Journal of Community Music, 7(1), 3-9.

Vaillancourt, G. (2012). Music therapy: A community approach to social justice. The Arts in Psychotherapy, 39(3), 173-178. doi: http://dx.doi.org/10.1016/j.aip.2011.12.011

van Eck, F. (2014). The role of the musician working with traumatized people in a war-affected area: Let the music happen. Journal of Applied Arts \& Health, 4(3), 301-311. 
Veblen, K. K., Messenger, S. J., Silverman, M., \& Elliott, D. J. (2013). Community music today: R\&L Education. 


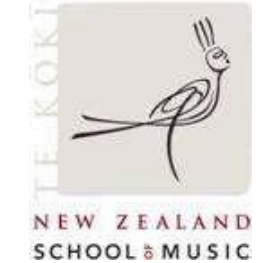

Music Therapy Dept. New Zealand School of Music, c/- Massey University, P0 Box 756, Wallace Street, Wellington. Tel: 04 463-5233 ext: $35807 / 35808$

To [redacted], Director of [redacted]

As part of the requirements for my music therapy clinical placement I am required to complete an exegesis, which will address my research question 'What is the role of a student music therapist in a community music setting?' I am writing to ask if I can describe my work at [redacted] in my research report.

The research uses data gathered at my placement, and as such will come from my observational and reflective notes on placement sessions, as well as audio recordings of meetings and conversations I have had with you, my research supervisor, other [redacted] team members, and certain participants at community music sessions. I will be writing separate consent forms to ask individuals for their permission for their data to be used in my exegesis.

The exegesis will be written up and submitted for examination. The examiners might be internal or external to the University of Victoria Wellington. The exegesis will also be printed and held by the University of Victoria library, where the public may access it. It will also be available online from the University's library website.

Please take time to think about this, and ask any questions you might have. When you are sure you agree that I can write about my placement at [redacted], please sign both copies of this letter, keep one, and give one back to me. If you would like a copy of the exegesis, it will be provided for you after the work has been completed and examined, following the conclusion of my placement.

Facility representative: [Removed to preserve anonymity]

Name: Signature:

Date...

This consent expires on and may be withdrawn at any time by contacting the Music

Therapy Programme Director at +64 44635233 x35807

Yours sincerely,

Sidharth Pagad 


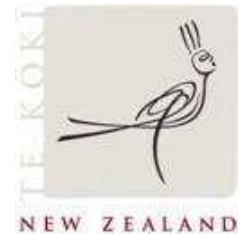

SCHOOL

Music Therapy Dept. New Zealand School of Music, c/- Massey University, P0 Box 756, Wallace Street, Wellington. Tel: 04 463-5233 ext: $35807 / 35808$

Hello, I am Sidharth Pagad, the music therapy student.

As part of the requirements for my music therapy clinical placement I am required to complete an exegesis, which will address my research question 'What is the role of a student music therapist in a community music setting?' I am writing to ask if I can use data from notes and/or audio recordings in my research report.

If you agree, the case study is likely to include some background information about you. Anonymity will be protected whenever possible, with all information that might identify you being removed. I will not use video material in my research report

The exegesis will be written up and submitted for examination. The examiners might be internal or external to the University of Victoria Wellington. The exegesis will also be printed and held by the University of Victoria library, where the public may access it. It will also be available online from the University's library website.

Please take time to think about this, and ask any questions you might have. When you are sure you agree that I can write about you in my research report, please sign both copies of this letter, keep one, and give one back to me. If you would like a copy of the exegesis, it will be provided for you after the work has been completed and examined, following the conclusion of my placement.

\section{Participant:}

Name: Signature:

Date...

This consent expires on and may be withdrawn at any time by contacting the Music

Therapy Programme Director at +64 44635233 ×35807

Yours sincerely,

Sidharth Pagad 


\section{Appendix C: ILLUSTRATIONS OF MethOdOLOgY IN ACTION- EXTRACT FROM A REFLEXIVE JOURNAL}

Note that I have highlighted phrases or words from this reflexive journal, and added codes with my reflections about them. These codes and their associated phrases were then collected together to further analyse.

$29^{\text {th }}$ May - African Drumming and Dancing

Tonight was the final of 4 African Drumming classes this term by Simon. We went over the 'Liberte' rhythm again, which is really quite a complex rhythm.

\section{[Focus on learning]}

Reece, Sonja and I kept the beat on dun-duns, which was fun, although Sonja had a difficult part, which she took a little while to get the hang of.

All in all, I felt like part of a smoothly operating team, and every rhythm was a new challenge for us to overcome. It felt like everybody was participating and joining in.

[Group members able to feel community and achievement through working toward musical product]

Reece did seem to have some difficulties though, and at times was not able to play the full beat, he would sometimes play along with a simpler beat, or wait and listen. It does seem to be a challenge to run a session where everybody is participating and are also pushed and stimulated, especially when group members are of different skill and experience levels.

[Balancing participation and musical 'richness' to stimulate individuals] 


\section{Appendix D: IlLustrations Of Methodology in ACtion- EXTRACT FROM AUDIO TRANSCRIPTION OF MEETING}

S: It's the same things that are happening, um, to talk for a minute about sing for your life, explicitly it's a singing group that comes together and sings every week.

[CM - explicitly about music]

Implicitly it's mostly older adults, and reading up about studies in the United Kingdom, they actually talk about Sing For Your Life there, and I don't know - I think Julian might have helped set it up over there - and they are talking about things like social exclusion, social benefits, psychological benefits - things like that

[CM - implicitly about therapeutic type benefits]

D: Yes, yes... So here, between the explicit and implicit, you're finding, that's where the boundary between the two is, isn't it?

[Boundary between $\mathrm{CM}$ and CoMT is between the explicit and the implicit]

S: Yes

D: Um, and you know there will be, as you know, there will be community musicians who are far more explicit about what is going on therapeutically, who look more like community music therapists and vice versa.

[Individual styles of facilitation can further blur the lines between CM and CoMT, implicit and explicit]

I mean you, with your experience, a couple of years down the track, might still look more like a community musician than a community music therapist and so, you know, it will just be people's individual, uh personalities, their level of training that they've had, the level of critique that they give their work - Because you know a community musician has no obligation to critique

[CM does not have an ethical obligation to critique non-musical aspects of their work] 
Well I'm not sure - but where are the ethical guidelines, and the community music therapist has an absolute obligation to critique at a significant depth, and what's going on and what they provide and all -

[COMT must reflect and critique their work in depth, to find what is going on, what they are providing]

S: Do you remember, um, we talked about it a few weeks ago, the ethical guidelines, and community musicians being guided by their moral compass -

[CMs guided by a personal moral compass]

D: Right

S: And music therapists having an institutionalised code

[Community music therapists, music therapists having an institutionalised code of ethics]

D: Right

S: And there being good and bad things about both

D: Yes absolutely 


\section{Appendix E: ILLUSTRATIONS OF METHOdOLOGY IN ACTION- EXTRACT FROM LIST OF CODES}

These codes were then put into categories, which served to form the seeds of the themes I found. Rather than a linear process, there was much backward and forward shuffling of data from one code to another, and codes from one category to another.
Raw
Line File
Category
Chronological

ID

\begin{tabular}{|c|c|c|c|c|}
\hline $\begin{array}{l}\text { CM Focus on musical } \\
\text { product }\end{array}$ & 73 & $\begin{array}{l}\text { Analysis } \\
\text { Audio }\end{array}$ & Music focused & 13 \\
\hline $\begin{array}{l}\text { CM providing new } \\
\text { avenues to musically } \\
\text { challenge and stretch } \\
\text { individuals and groups }\end{array}$ & 343 & $\begin{array}{l}\text { Analysis } \\
\text { Audio }\end{array}$ & Music centred & 34 \\
\hline $\begin{array}{l}\text { CM brings people } \\
\text { together for a common } \\
\text { musical goal }\end{array}$ & 386 & $\begin{array}{l}\text { Analysis } \\
\text { Audio }\end{array}$ & Music focused & 38 \\
\hline $\begin{array}{l}\text { CM - explicitly about } \\
\text { music }\end{array}$ & 537 & $\begin{array}{l}\text { Analysis } \\
\text { Audio }\end{array}$ & Music focused & 46 \\
\hline $\begin{array}{l}\text { CM does not have an } \\
\text { ethical obligation to } \\
\text { critique non-musical } \\
\text { aspects of their work }\end{array}$ & 555 & $\begin{array}{l}\text { Analysis } \\
\text { Audio }\end{array}$ & Music focused & 50 \\
\hline $\begin{array}{l}\text { CMs responsibility is } \\
\text { with the music. }\end{array}$ & 662 & $\begin{array}{l}\text { Analysis } \\
\text { Audio }\end{array}$ & Music focused & 61 \\
\hline $\begin{array}{l}\text { CM adjusting to } \\
\text { musical needs of the } \\
\text { group }\end{array}$ & 843 & $\begin{array}{l}\text { Analysis } \\
\text { Audio }\end{array}$ & Music centred & 76 \\
\hline $\begin{array}{l}\mathrm{CM} \text { - not as much } \\
\text { verbal interaction - } \\
\text { focus on the music }\end{array}$ & 869 & $\begin{array}{l}\text { Analysis } \\
\text { Audio }\end{array}$ & Music focused & 77 \\
\hline $\begin{array}{l}\text { CM's approach stems } \\
\text { from the musical } \\
\text { experience that is being } \\
\text { sought }\end{array}$ & 877 & $\begin{array}{l}\text { Analysis } \\
\text { Audio }\end{array}$ & Music focused & 78 \\
\hline $\begin{array}{l}\text { A shared musical } \\
\text { experience underpins } \\
\text { CM }\end{array}$ & 912 & $\begin{array}{l}\text { Analysis } \\
\text { Audio }\end{array}$ & Music focused & 80 \\
\hline $\begin{array}{l}\text { CM is watching the } \\
\text { group, guiding } \\
\text { individuals' and } \\
\text { group's musical } \\
\text { experience }\end{array}$ & 941 & $\begin{array}{l}\text { Analysis } \\
\text { Audio }\end{array}$ & Music focused & 81 \\
\hline
\end{tabular}




\begin{tabular}{l|l|l|l|l|}
\hline $\begin{array}{l}\text { CM is aware of musical } \\
\text { dynamic of group, and } \\
\text { changes in the dynamic }\end{array}$ & 972 & $\begin{array}{l}\text { Analysis } \\
\text { Audio }\end{array}$ & Music focused & 84 \\
\hline $\begin{array}{l}\text { CM almost solely } \\
\text { focused on the musical } \\
\text { experience, and } \\
\text { affecting the musical } \\
\text { experience }\end{array}$ & 975 & $\begin{array}{l}\text { Analysis } \\
\text { Audio }\end{array}$ & Music focused & 85 \\
\hline $\begin{array}{l}\text { Type of musical } \\
\text { experience in CM } \\
\text { group defines the } \\
\text { outcomes and benefits } \\
\text { of that group. }\end{array}$ & 1004 & $\begin{array}{l}\text { Analysis } \\
\text { Audio }\end{array}$ & Music focused & 90 \\
\hline
\end{tabular}




\section{Appendix F: ILLUSTRATIONS OF MethOdOLOgy IN ACTION - EXTRACT FROM WORKING 'CATEGORIES' FILE}

When the categories were more or less settled upon, descriptions were made for each category, and these were later expanded into the subheadings within the findings section of this research study.

\begin{tabular}{|c|c|c|c|}
\hline Category & Frequency & What is this about & $\begin{array}{l}\text { Related reading } \\
\text { ID }\end{array}$ \\
\hline Music centered & 78 & $\begin{array}{l}\text { Enjoyment, positive outcomes etc. } \\
\text { coming through the music itself }\end{array}$ & $6,19,22$ \\
\hline Music focused & 66 & $\begin{array}{l}\text { Focus on musical product, or musical } \\
\text { outcome as an end in itself }\end{array}$ & $2,3,8,14,19,30$ \\
\hline $\begin{array}{l}\text { Educational } \\
\text { focus }\end{array}$ & 52 & $\begin{array}{l}\text { CM's focus on teaching, learning, } \\
\text { building musical skills, and mastery }\end{array}$ & $\begin{array}{l}2,8,12,16,19 \\
26\end{array}$ \\
\hline Musical support & 40 & $\begin{array}{l}\text { CM musically supporting group, often } \\
\text { through accompaniment (instrumental } \\
\text { or vocal) }\end{array}$ & \\
\hline $\begin{array}{l}\text { Resourcing } \\
\text { participation }\end{array}$ & 31 & $\begin{array}{l}\text { CoMT resourcing participation in a } \\
\text { group }\end{array}$ & 2,25 \\
\hline $\begin{array}{l}\text { Musical } \\
\text { facilitation skills }\end{array}$ & 27 & $\begin{array}{l}\text { Building, observing or engaging in } \\
\text { musical facilitation skills such as } \\
\text { cueing people into starting a song, } \\
\text { facilitating rounds, rhythm games etc. }\end{array}$ & \\
\hline $\begin{array}{l}\text { Establish } \\
\text { shared musical } \\
\text { experience }\end{array}$ & 26 & $\begin{array}{l}\text { needing to establish a shared musical } \\
\text { experience within a CM group, as this } \\
\text { is the primary bond which holds the } \\
\text { group together }\end{array}$ & 12 \\
\hline $\begin{array}{l}\text { Implicit } \\
\text { Benefits }\end{array}$ & 24 & $\begin{array}{l}\text { Implicit non-musical or people } \\
\text { oriented benefits in CM }\end{array}$ & $\begin{array}{l}6,15,18,23,24 \\
26,27,34,40\end{array}$ \\
\hline $\begin{array}{l}\text { Process between } \\
\text { music }\end{array}$ & 23 & $\begin{array}{l}\text { A lot of group process happens in } \\
\text { before and after CM sessions, during } \\
\text { tea-breaks, packing and unpacking } \\
\text { instruments etc. }\end{array}$ & 19 \\
\hline Unsure of role & 21 & $\begin{array}{l}\text { me being confused, unsure or anxious } \\
\text { about what my role is, what I am } \\
\text { supposed to be doing }\end{array}$ & \\
\hline $\begin{array}{l}\text { Group } \\
\text { supporting CM }\end{array}$ & 12 & $\begin{array}{l}\text { Group members helping community } \\
\text { musician, whether musically, or by } \\
\text { offering feedback or emotional support } \\
\text { for a learning CM, or through } \\
\text { logistical support such as helping } \\
\text { pack/unpack instruments }\end{array}$ & 15 \\
\hline
\end{tabular}




\section{Appendix G: Illustrations of Methodology in Action - PROCESS VS PRODUCT- DESCRIBING THE DATA THROUGH THE LENS OF CATEGORIES AND THEMES AS A RESULT OF USING THEMATIC ANALYSIS}

Here is a working file illustrating the process of my findings being worked out. Category descriptions have been listed, and the points from these descriptions are being worked into a final form to go into the research report.

\section{Process vs Product}

\section{Needs Based}

This category refers to how CoMT work is often needs based, and a shared need underpins the purpose of a CoMT group. This means a CoMT group already has an identity without the need of a shared musical bond. CoMT is implicitly music centred, but explicitly centred on the people, and achieving a specific goal that will help address the shared need of the group. This is another important distinction between CM and CoMT

\section{Music Focused}

What brings a CM group together is a common musical goal. These codes refer to CM's emphasis on a musical product, and how music in itself is the most important (explicit) outcome for these groups. Things like the $\mathrm{CM}$ not having much focus on verbal or other nonmusical interaction come up. The type of musical experience defines what the group is too, which goes back to the fact that the group purpose is based on the advertised musical experience.

There are codes about the emphasis on musical accuracy, the community musician's focus and responsibility for the musical value of what the group puts out (involves preparation etc.). The fact that group process and group needs sometime become a second priority to the musical goal.

This means that sometimes newcomers to a CM group might feel isolated, especially if they do not yet have the skills or experience to musically participate in the group. 


\section{Reflexive}

This category refers to the fact that community music therapists have to be reflexive about their work, always questioning - "Why am I doing this? What benefits does it have? Why do people attend this group?"

This relates to the institutionalised code of ethics that music therapists adhere to, and the fact that they can work with more vulnerable populations because of these codes. It is one distinct difference between CM and CoMT.

As a music therapy student, my research role also required me to be highly reflexive about what I was doing, and why I was doing it. 